\title{
Continuous glucose monitoring - proved hypoglycemia in sodium-glucose co-transporter-2 inhibitors - treated type 2 diabetes patients: a link to ketosis development
}

\author{
Shmuel Levit ${ }^{1,2}$ Shmuel Giveon ${ }^{3}$, Ildar Musin ${ }^{4}$, Royi Barnea ${ }^{5}$, Ifat Korek-Abadi ${ }^{6}$, \\ Vyacheslav Levit ${ }^{7}$, Darian Ryder ${ }^{8}$, Chen Hanna Ryder 8,10 \\ ${ }^{1}$ Institute of Endocrinology, Diabetes \& Metabolism, Assuta Medical Center, Tel-Aviv, Israel \\ ${ }^{2}$ National Research Technological University, Kazan, Russia \\ ${ }^{3}$ Sackler School of Medicine, Tel-Aviv University, Tel-Aviv, Israel \\ ${ }^{4}$ National Research Technological University, Kazan, Russia \\ ${ }^{5}$ Assuta Research Institute, Assuta Medical Center, Tel-Aviv, Israel \\ ${ }^{6}$ Department of Academy and Research, Assuta Medical Center, Tel-Aviv, Israel. \\ ${ }^{7}$ Department of Disease prevention, City Clinical Hospital №8, Chelyabinsk, Russia \\ ${ }^{8}$ Virtual-Reality \& Neuro Cognition Lab, Technion - Israel Institute of Technology, Haifa, Israel \\ ${ }^{9}$ Brain Research Laboratory, Department of Neurology, Ziv Medical Center, Safed, Israel \\ ${ }^{10}$ Faculty of Medicine, Bar-llan University, Safed, Israel
}

\begin{abstract}
Background: Latest studies have shown the remarkable ability of sodium-glucose co-transporter2 inhibitors (SGLT2i) to reduce cardiovascular morbidity and mortality. However, real-life data and the results of several other studies seem to contradict these outcomes, pointing out possibilities of serious side effects. Ketoacidosis (KA) remains one of the most dangerous complications, yet, not fully understood. All of the above urgently requires real-practice data, which may shed some light on side effects of this novel anti-diabetic drug family.

Aims: To investigate the real-life rates of hypoglycemia and ketosis (K) in SGLT2i treated patients, using Continuous Glucose Monitoring (CGM) and capillary blood $\beta$-hydroxybutyrate measurements.

Methods: We report the results of a two-year retrospective analysis of 136 Type 2 Diabetes (T2DM) patients, all (100\%) treated with a SGLT2i, combined with Metformin or Metformin with Incretin-Based Therapy (Mt-IBT). CGM recordings were done in 52 persons. In 9 patients (Group A), CGM-proved hypoglycemic episodes were discovered. The rest of 43 patients (Group B) didn't show any hypoglycemia. Three patients in Group A and 11 from Group B were also treated with small doses of basal insulin on admission; the insulin was later discontinued in all patients of Group A and seven patients of Group B. Main characteristics of two groups were subsequently compared.

Results: CGM data analysis showed significantly lower average Sensor Glucose (SG) , 7.2 \pm 1.3 vs. 8.2 1.7 $\mathrm{mmol} / \mathrm{l}, \mathrm{p}=0.04$, and estimated $\mathrm{HbA}_{1 \mathrm{c}}, 6.1 \pm 0.7 \mathrm{vs.} 6.8 \pm 1.1 \%, \mathrm{p}=0.02$, in Group A patients.

We also report three cases of ketosis, proved by elevated capillary $\beta$-hydroxybutyrate concentrations. Pathophysiological link between frequent hypoglycemia rates (Six patients without insulin treatment 11.5 $\%$ in total CGM group of 52 patients)) and ketosis development (Three patients (2.2\% in total cohort of 136 participants)) was suggested.

Conclusions: More frequent than previously reported rates of hypoglycemia and ketosis were discovered in patients taking SGLT2 inhibitors. Pathophysiological link between the two conditions is assumed. More studies are needed to confirm our hypothesis.
\end{abstract}

\section{KEYWORDS}

Diabetes mellitus, type 2; Sodium-Glucose Co-transporter-2 Inhibitors; Ketoacidosis; Ketosis; Beta-hydroxybutyrate; Continuous Glucose Monitoring; Hypoglycemia; Hypoinsulinemia; IncretinBased therapy. 


\title{
Гипогликемия, доказанная непрерывным мониторингом глюкозы у пациентов со вторым типом диабета, получающих ингибиторы натрий-глюкозного котранспортера-2: связь с развитием кетоза
}

\author{
Левит Ш. ${ }^{1,2}$, Гивон Ш. ${ }^{3}$, Мусин И.н. ${ }^{4}$, Барнеа Р. ${ }^{5}$, Корек-Абади И. ${ }^{6}$, Левит В. , Райдер Д. ${ }^{8}$, \\ Райдер X.
}

' Институт эндокринологии, диабета и обмена веществ, Медицинский центр Ассута,Тель-Авив,

Израиль

${ }^{2}$ Казанский национальный исследовательский технологический университет, Казань, Россия

${ }^{3}$ Тель - Авивский университет. Медицинский факультет им. Сакклера, Израиль

${ }^{4}$ Казанский национальный исследовательский технологический университет, Казань, Россия

${ }^{5}$ Исследовательский институт Ассута, Медицинский центр Ассута, Тель-Авив, Израиль

${ }^{6}$ Отдел научных исследований, Медицинский центр Ассута, Тель-Авив, Израиль

${ }^{7}$ Отделение профилактики, Городская клиническая больница №8, Челябинск, Россия

8 Лаборатория виртуальной реальности и нейрокогнитивных технологий, Технион, Израильский технологический университет, Хайфа, Израиль

9 Лаборатория исследования мозга, отделение неврологии, Медицинский центр Зив, Цфат, Израиль

${ }^{10}$ Медицинский факультет, университет Бар-Илан, Цфат, Израиль

\section{PEЗЮME}

Актуальность исследования: Последние исследования показали замечательную способность ингибиторов натрий-глюкозного котранспортера-2 (SGLT2i) снижать сердечно-сосудистую заболеваемость и смертность. Однако реальные данные и результаты ряда других исследований, по-видимому, противоречат этим посылам, указывая на возможность серьезных побочных эффектов. Кетоацидоз (КА) остается одним из самых опасных осложнений, пока еще не до конца изученных. Все вышеперечисленное срочно требует данных реальной практики, которые могут пролить свет на побочные эффекты этого нового семейства антидиабетических препаратов.

Цель: Изучить реальные показатели гипогликемии и кетоза (K) у пациентов, принимавших ингибиторы SGLT2i, используя непрерывный мониторинг глюкозы (CGM) и измерения $\beta$-гидроксибутирата в капиллярной крови.

Методы: Мы сообщаем о результатах двухлетнего ретроспективного анализа 136 пациентов с сахарным диабетом 2 типа (T2DM), всех (100\%), получавших лечение ингибиторами SGLT2і в сочетании с метформином (МТ) или метформином с терапией на основе инкретин (МT-IBT). Записи CGM были сделаны у 52 человек. У 9 пациентов (группа А) были обнаружены подтвержденные CGM гипогликемические эпизоды. У остальных 43 пациентов (группа В) гипогликемии не было обнаружено. 3 пациента из группы А и 11 из группы В также получали небольшие дозы базального инсулина при поступлении; позднее инсулин был отменен у всех пациентов группы А и 7 пациентов группы В. Затем были сопоставлены основные характеристики двух групп.

Результаты: Анализ данных CGM показал достоверно более низкое среднее содержание глюкозы по сен-

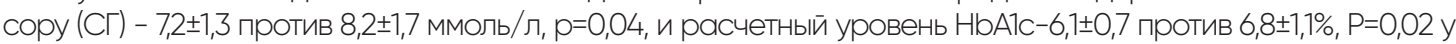
пациентов группы А. Мы также сообщаем о трех случаях кетоза, подтвержденных повышенными уровнями капиллярными уровнями $\beta$-гидроксибутирата в капиллярной крови. Установлена патофизиологическая связь между частотой гипогликемий (6 пациентов без инсулинотерапии (11,5\% в общей группе ЦГМ из 52 пациентов)) и развитием кетоза (3 пациента (2,2\% в общей когорте из 136 участников)).

Выводы: Более частые, чем сообщалось ранее, показатели гипогликемии и кетоза были обнаружены упациентов, принимавших ингибиторы SGLT2. Предполагается патофизиологическая связь между этими двумя состояниями. Для подтверждения нашей гипотезы необходимы дополнительные исследования.

\section{КЛЮЧЕВЫЕ СЛОВА}

Сахарный диабет 2 типа; ингибиторы натрий-глюкозного котранспортера-2; кетоацидоз; кетоз; бета-гидроксибутират; непрерывный мониторинг глюкозы; гипогликемия; гипоинсулинемия; терапия на основе инкретинов. 


\section{BACKGROUND}

Sodium-glucose cotransporter 2 inhibitors (SGLT2i) are a relatively novel class of antidiabetic medications. Latest studies have shown their remarkable ability to decrease cardiovascular morbidity and mortality, while significantly reducing body weight and glucose levels $[1,2]$.

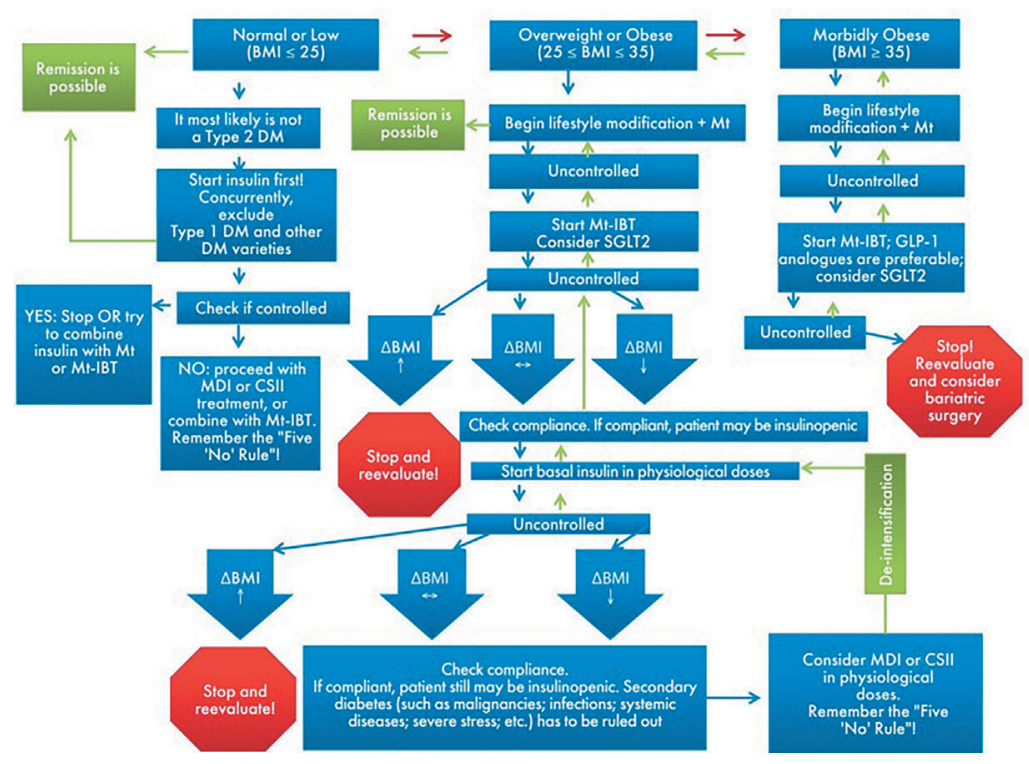

Figure 1(a) The Gravicentric Algorithm for Diabetes Treatment (uplated and corrected). SGLT2 - Sodium - glucose co-transporter 2 inhibitors; GLP-1 - Glucagon - like peptide-1 CSII - Continuous Subcutaneous Insulin Infusions (pump therapy); MDI - Multiple Daily Injections; Mt - Metformin; MT-IBT - Metformin + Incretin-Based Therapy; OAD - Oral Antidiabetic Drugs; Delta - Difference between basal and current measurement; Psysiological doses of basal Insulin $\leq 0.4 \mathrm{U} / \mathrm{kg}$; Psysiological doses of Total Daily Insulin $\leq 0.6 \mathrm{U} / \mathrm{kg} ; \uparrow$ Growing parameter; $\leftrightarrow$ Stable parameter

Five "No" Rule:

- No cascade "add-on" therapies to obese (overweight)

patient with a positive weight balance (progressive weight gain)

- No weight gain allowed regardless the type of treatment

- No prescription of pro-energetic agents

- No chronic insulin therapy for morbidly obese patient

- No supra-physiological doses (more than 0.5-0.6 U/kg of

current body weight) of insulin.

Рис. 1 (а) Гравоцентрический алгоритм лечения диабета (дополненный и исправленный). SGLT2 - ингибиторы натриево-глюкозного ко-транспортера 2; GLP-1 - глюкагоноподобный пептид-1

CSII - непрерывные подкожные инфузии инсулина (помповая терапия); MDI - многократные ежедневные инъекции; Mt - метформин; MT-IBT - терапия метформином + инкретин; $\mathrm{OAD}$ - пероральные противодиабетические препараты; Дельта - разница между базальным и текущим измерением; Психологические дозы базального инсулина $\leq 0,4$ ед / кг; Психологические дозы общего суточного инсулина $\leq 0,6$ ед / кг; Parameter растущий параметр; $\leftrightarrow$ Стабильный параметр

Правило пяти «нет»:

• Нет каскадной «дополнительной» терапии ожирения (избыточный вес)

пациент с положительным балансом веса (прогрессивное увеличение веса)

- Не допускается увеличение веса, независимо от типа лечения

- Нет рецепта проэнергетических агентов

• Нет хронической инсулиновой терапии для пациентов с патологическим ожирением

• Никаких надфизиологических доз (более 0,5-0,6 Ед / кг

текущая масса тела) инсулина.
The data of the EMPA-REG study came as a surprise for those who expected the results to be more modest. Indeed, most researchers are puzzled as to the actual reasons for such a high efficacy. However, real-life data and the results of several other studies seem to contradict these outcomes, pointing out possibilities of serious side effects, such as renal impairment, urinary tract and genital infections, ketoacidosis (KA), and even toe amputations[3-10]

Recent publication indicates SGLT2i at least double the risk of ketoacidosis (KA) [11].

Still, the causes and real frequency of 'Euglycemic ketoacidosis' remain as vague as the term itself [12, 13]. Thus, the Pharmacovigilance Risk Assessment Committee (PRAC) of the European Medical Agency (EMA) calls this condition "atypical"[14]. Authors also specify that low reserve of insulin-secreting cells, food intake restriction and sudden reduction in insulin concentration are the main culprits of ketosis.

Increased fracture risk is another concern clinician should be aware of. In September 2015, the FDA has issued a safety warning specifically noting increased risk for fractures in patients receiving Canagliflozin[15]. Although the warning was limited to just one drug, the FDA notes that they are continuing to evaluate the risk for bone fractures with other drugs in the SGLT2i class.

As for hypoglycemia occurrence, it was suggested that SGLT2i per se do not cause it, until combined with some well-known hypoglycemic agents like Insulin, Sulfonylurea or Glinides. As for a combination of SGLT2 with anti-hyperglycemic agents like GLP-1analogues, Metformin, DPP4 inhibitors etc., SGLT2i were claimed "hypoglycemia - safe"[16-18]. All of the above urgently requires real-practice data, which may shed some light on those not fully understood effects of this novel antidiabetic drug family[19].

\section{Primary objectives}

The aim of the study was to investigate the real-life rates of hypoglycemia and ketosis (K) in SGLT2i - treated patients with Continuous Glucose Monitoring (CGM) and capillary blood $\beta$-hydroxybutyrate measurements.

\section{Secondary objectives}

To reveal the factors predisposing to Hypoglycemia and Ketosis development

Methods

Study design

We provide one-center retrospective-controlled pilot clinical trial. The overall design of this study presented on Figure 1b.

\section{Participant's selection and groups forming}

Inclusion criteria. For primary evaluation, we have included medical records of all 136 T2DM ambulatory 
patients in our institute, who were treated with SGLT2 from August 2014 to August 2016, when retrospective analysis was completed. Of those, medical records of 52 patients who performed a routine CGM on SGLT2i therapy were separately assessed. Hypoglycemia was routinely defined as reduction of Sensor Glucose (SG) below $70 \mathrm{mg} \%$ (3.9 $\mathrm{mmol} / \mathrm{l})$.

Exclusion criteria. Patients were not included in the study if the following criteria were met:

- type of diabetes other than T2DM;

- severe intercurrent diseases like infections, systemic connective tissue diseases, renal failure with glomerular filtration rate (GFR) less than $50 \mathrm{ml} / \mathrm{min}$, severe chronic heart failure; liver insufficiency; severe respiratory malfunction; active stages of cancer;

- age less than 30 years at a moment of starting SGLT2i (as to prevent accidental type 1 diabetes (T1DM) inclusion);

- hospitalized patients.

The subgroup of patients with CGM-confirmed hypoglycemia was allocated. Collected data were subsequently compared between the two patient groups:

- Group A - "Hypoglycemia" - 9 patients;

- Group B -"Non-hypoglycemia" - 43 patients.

In order to further confirm the impact of SGLT2i in hypoglycemia development we compared the sensorderived hypoglycemia Time-in-range (hypo-TIR) in group "A" with the hypo-TIR in the control group. Patients of control group were not the members of 136 patients of our study cohort and were analyzed from the data of parallel study (the paper is pending) and included all patients who performed CGM in this study. Of note, the patients of this control group were treated according to the very same (Gravicentric) treatment algorithm and by the same medical stuff (Figure 1a). Moreover, all of them have reached the same estimated $\mathrm{HbA} 1 \mathrm{c}$ level of $\leq 7,0 \%$, but without implementation of SGLT2i, which is generally prescribed in our institute as a third-line therapy (when Metformin and Incretinbased therapy only partially succeed).

The subgroup of three patients who developed ketosis was analyzed separately. Forth case of severe KA (after study closure) will be reported later in this paper.

\section{Study endpoints}

As the primary endpoints we evaluate a real-life and precise rate of hypoglycemia events derived as hypo-TIR on CGM, and a real-life and precise rate of ketosis derived from regular measurements of $\beta$-hydroxybutyrate in capillary blood.

\section{Medical interventions protocol and study endpoints registering methods}

Treatment program for all study participants as well as for control group of patients was based on our recently updated Gravicentric (Energetic) (in opposite to Glucocentric) approach, where reduction of patient's weight (Gravis, Lat. - heavy) through restoration of

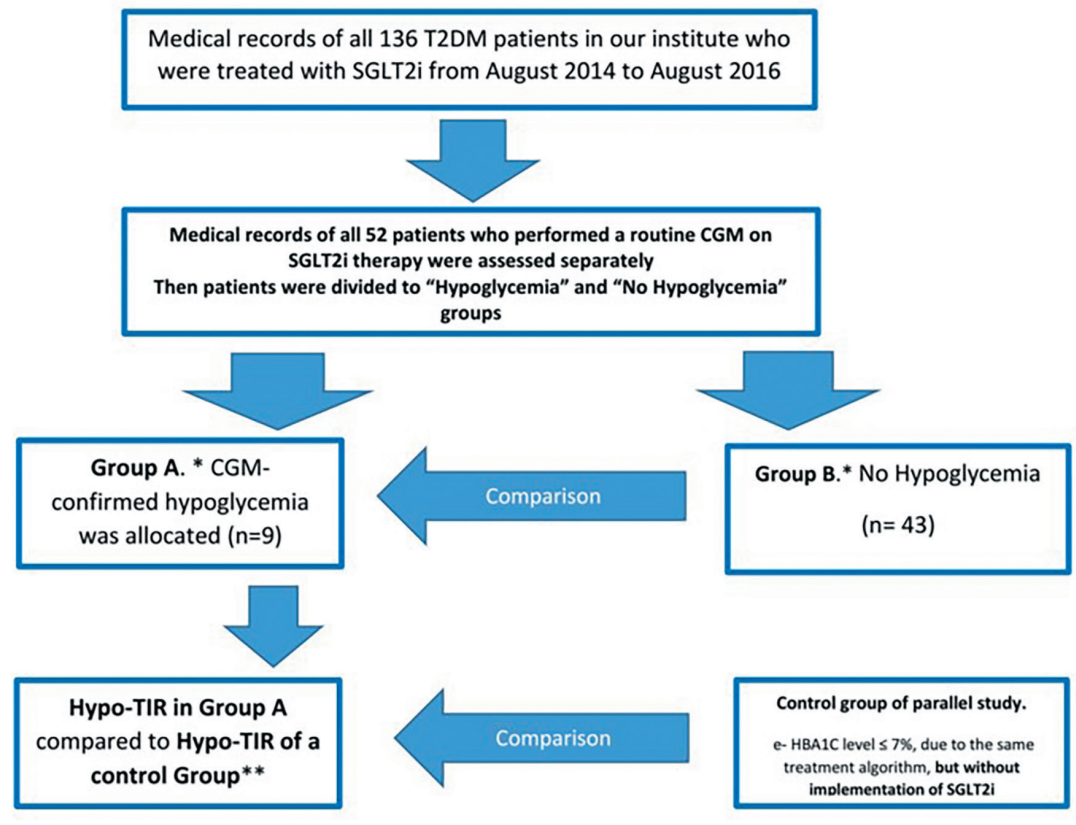

Figure $1 b$. Study design. All patients were treated with the help of the same therapeutic algorithm (see the text for further explanation).

energy balance is of the highest priority (fig. 1a). Our therapeutic approach is based on several fundamental points (all of them were published previously) $[20,21,22]$. Thus, study patients were treated with Metformin, dipeptidyl peptidase 4 (DPP-4) inhibitors or GLP-1 (glucagon-like peptide-1analogue, Liraglutide). This is so-called, Mt-IBT (Metformin plus IncretinBased Therapy) approach. SGLT2i was added later on. Eleven of 52 patients (25.6\%) with no hypoglycemia at CGM and three patients (33.3\%) in whom hypoglycemia was revealed, were treated with small amounts of additional basal insulin (an average dose of $25.6 \mathrm{U} /$ day) at the moment of CGM recording. These patients were initially treated by Multiple Daily Injections (MDI) of insulin at the time of admission to our clinic. In these persons, Mt-IBT (Metformin plus Incretin Based Therapy), and later on SGLT2i, were started as addition to intensive insulin therapy in order to bring about weight reduction along with de-escalation of insulin treatment. Indeed, insulin dose was significantly reduced and multiple daily injections (MDI) were soon substituted by only one injection of basal insulin. Subsequently, the insulin treatment was completely discontinued in three patients of Group A and seven patients of Group B.

CGM. Our institute practices routine professional 'blind' Continuous Glucose Monitoring (CGM) recordings (iPro ${ }^{\circledR 2}$, Medtronic, USA) in all types of diabetes patients. We consider CGM to be the "ECG of diabetes" and recommend its performance to every diabetes patient, especially in those who change their treatment program. Unfortunately, professional CGM has not yet been approved by our health funds as a routine medical procedure for T2DM patients. Hence, patients are forced to perform CGM recordings at their own expense. Therefore, we carry out CGM recordings only in some of our T2DM patients.
${ }^{\star}$ CGM - derived data from Group

A and Group B were compared statistically.

${ }^{* *}$ In order to further confirm the impact of SGLT2i in hypoglycemia

development we compared the sensor-derived hypoglycemia Timein-range (TIR) in group A with the TIR in the control group. Patients of control group were not the members

of 136 patients of our study cohort and were analyzed from the data of parallel study. They have reached the estimated $\mathrm{HbA}_{1 \mathrm{c}}$ level $<7 \%$, due to

the same treatment algorithm, but without implementation of SGLT2i.

Рисунок 1б. Дизайн исследования. Все пациенты лечились с помощью одного и того же терапевтического алгоритма (см. Текст для дальнейшего объяснения).

* Данные CGM, полученные из группы А и группы B,

сравнивались статистически.

** Чтобы дополнительно подтвердить влияние SGLT2i на развитие гипогликемии, мы сравнили временную шкалу

гипогликемии, вызванную датчиком (TIR) в группе A, с TIR в контрольной группе. Пациенты контрольной группы не были членами 136 пациентов нашей группы исследования и были проанализированы по данным параллельного исследования

Они достигли предполагаемого уровня $\mathrm{HbA}_{1 \mathrm{c}}<7 \%$, благодаря тому же алгоритму лечения, но без применения SGLT2i. 


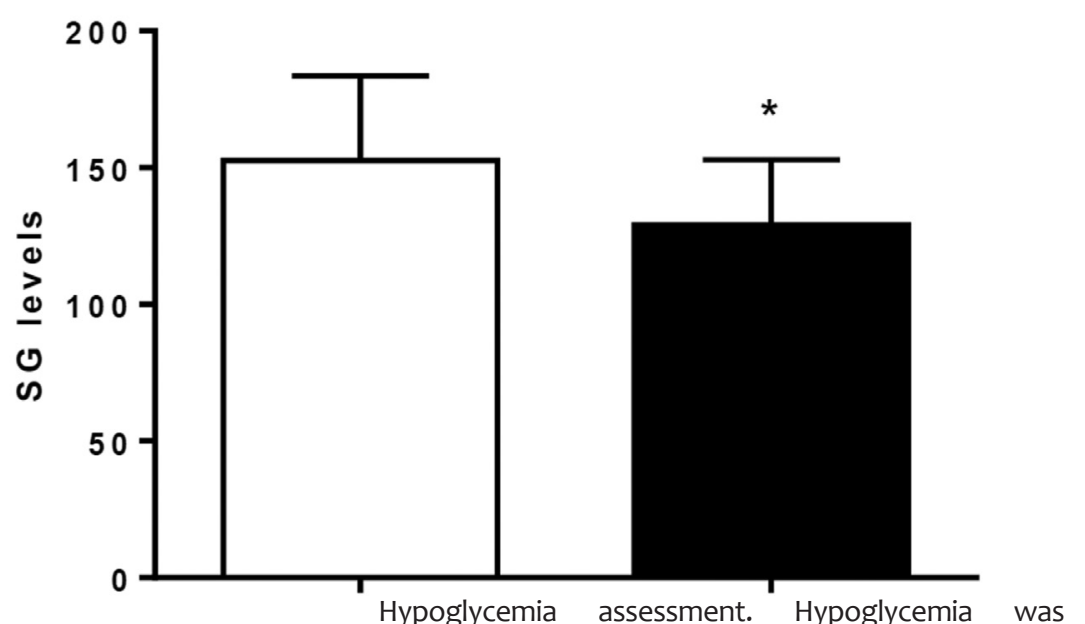

Figure 2 (A) Average SG (mg \%) in Groups A (Hypoglycemia) and B (No Hypoglycemia). Sensor Glucose (SG) in $\mathrm{mmol} / \mathrm{l}$ : $7.2 \pm 1.3$ vs. $8.2 \pm 1.7 \mathrm{mmol} / \mathrm{l}$, $\mathrm{p}=0.04$. Student's T-test.

Рисунок 2 (А) Средний SG (мг\%) в группах A (гипогликемия) и В (без гипогликемии). Сенсорная глюкоза (SG) в ммоль / л: 7,2 \pm 1,3 против 8,2 $\pm 1,7$ ммоль / л, $\mathrm{p}=0,04$. Студенческий Т-тест.

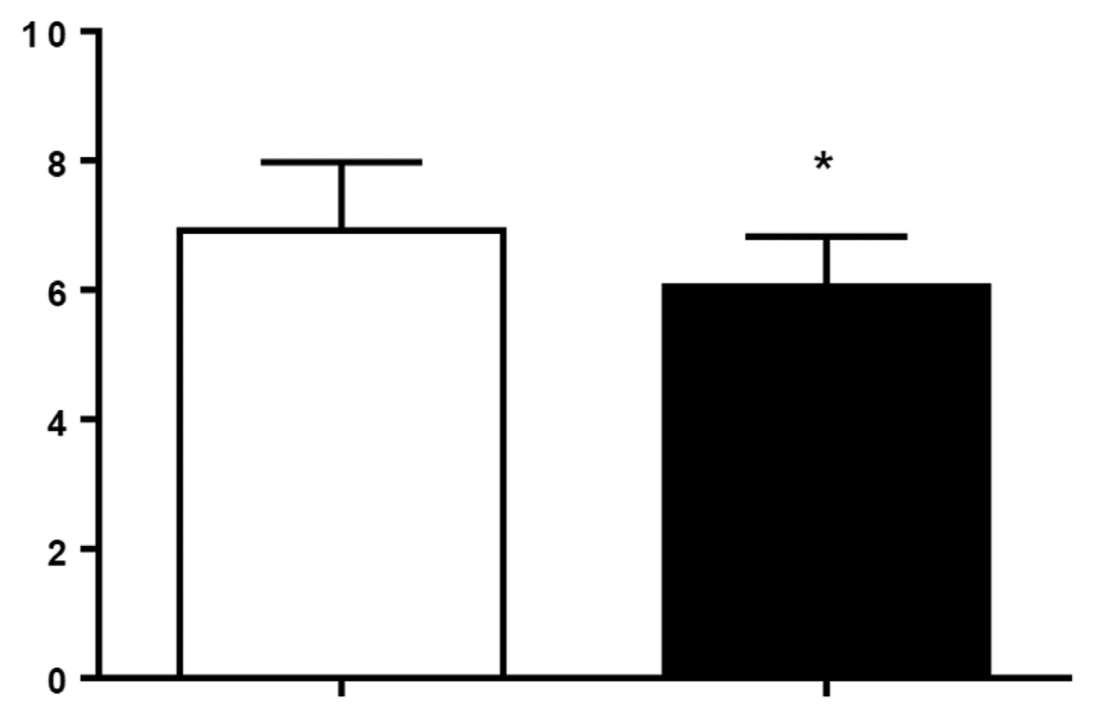

Figure 2 (B) Estimated $\mathrm{HbA}_{\mathrm{lc}}$ levels in groups A (Hypoglycemia) and B (No Hypoglycemia) and estimated $\mathrm{HbA}_{1 \mathrm{c}}-6.1 \pm 0.7$ vs. $6.8 \pm 1.1 \%$, $\mathrm{p}=0.02$, Student T-test.

Рисунок 2 (В) Оцененные уровни $\mathrm{HbA}_{1 \mathrm{c}}$ в группах А (гипогликемия) и В (без гипогликемии) и предполагаемый $\mathrm{HbA}$ - 6,1 \pm 0,7 против $6,8 \pm 1,1 \%, \mathrm{p}=0,02$, Студенческий Т-тест..

Ketosis assessment. Virtually every T2DM patient starting SGLT2i in our institute receives a kit to measure $\beta$-hydroxybutyrate concentration in capillary blood (Free Style Optium, Abbott, USA). The evaluation of ketosis relies on routine conventional gradation of $\beta$-hydroxybutyrate concentration:

- $<0.6 \mathrm{mmol} / \mathrm{l}$ - a normal blood ketone value;

- $0.6-1.5 \mathrm{mmol} / \mathrm{l}$ - indicates that more ketones are being produced than normal, (test again later to see if the value has lowered);

- 1.6-3.0 mmol/l - a high level of ketones and could present a risk of ketoacidosis (KA), (it is strongly recommended to contact healthcare team for advice);

- >3.0 mmol/l - a dangerous level of ketones, which will require immediate medical care.

We ask our patients to measure their capillary $\beta$-hydroxybutyrate once a week in the morning, before meals. Patients whose $\beta$-hydroxybutyrate levels were over $2.0 \mathrm{mmol} / \mathrm{L}$ (performed twice) were considered to be experiencing ketosis $(K)$, regardless of their clinical signs. These patients were instructed to immediately stop SGLT2i and to inform their treating physicians.

\section{Ethics approval}

This study was carried out in accordance with the recommendations of 'Helsinki declaration guidelines, Human Experimentation Committee'. The protocol was approved by the 'Human Experimentation committee', approval number is $16-0090 \mathrm{ASMC}$

\section{Statistics}

Statistical analysis was performed using SPSS software version 23. Continuous variables are presented as means \pm SD and dichotomous/categorical variables as proportions. The normality of the distribution of continuous variables was assessed by the KolmogorovSmirnov test. If normality was rejected, non-parametric (Mann-Whitney) tests were used. $P<0.05$ was selected as the $\mathrm{p}$ - value for statistical significance.

\section{Results}

The main patient's characteristics and study results are reflected in Tables 1 and 2. A retrospective analysis of 136 files of all SGLT2i treated patients was performed. Of 136 participants, 52 patients made professional CGM (24 males and 28 females). The mean age was $59.4 \pm 10.6$ years and mean diabetes duration was $14.8 \pm 8.5$ years. In all 52 patients, sensor data analysis was performed routinely. Surprisingly, hypoglycemia was found in nine patients, (17.3\% of all CGM-documented cases): four from the Dapagliflozin subgroup and five from the Empagliflozin subgroup. Chi-square test revealed a nonsignificant trend between these two medications. ( $p$ $=0.2$ ). In Group A, three of the nine patients reported clinical signs of mild (non-severe) hypoglycemia (none of them received insulin) and two patients were able to neutralize it with food. In other words, six persons (11.5\% of all CGM-documented cases) did not get any

Main patient's characteristics, like mean age, mean diabetes duration, gender, baseline HbA1c levels, last estimated levels of HbA1c on CGM, last average Sensor Glucose (SG), $\triangle \mathrm{HbA} 1 \mathrm{C}$ (basal HbA1c - estimated HbA1c), number of patients receiving Metformin; number of patients receiving DPP-4-i, number of patients receiving GLP-1 analogues, number of patients receiving basal insulin at the time of CGM were analyzed.

No differences between the groups were discovered, besides last average SG (was significantly lower in Hypoglycemia group - Group $\mathrm{A}, \mathrm{p}=0.04$ ), and last estimated levels of HbA1c on CGM, which also was significantly lower in patients from Group $A(p=0.02)$. These findings probably reflect a well - known formula: the more precisely we control the diabetes, the more likely the patient is to have hypoglycemia (see Fig. 2a and 2b).

Of note, Insulin was subsequently withdrawn in ten patients (19.2\%), whose glycemic control remained excellent, in full accordance to our de- intensification approach.[21] medication, known to belinked directly to Hypoglycemia. 


\section{Sub analysis of the 'Hypoglycemia' group}

Out of nine patients with documented hypoglycemia, presence of hypoglycemia in three Insulin-treated patients was not surprising and could likely be attributed to insulin itself.

\section{The following are examples:}

In a 36-year-old woman (Patient 3 in Table 3), Dapagliflozin was started as part of the insulin deintensification process. Insulin Degludec (Tresiba) dose was reduced from 24 to only 10 units/ day. Nevertheless, patient still was able to enter the prolonged ( $T I R=4$ hours and 30 minutes) hypoglycemia with minimal Sensor Glucose (SG) of $50 \mathrm{mg} \%$. These hypoglycemic events completely resolved after insulin withdrawal.

A 69-year-old patient (patient 4 in table 3), showed prolonged hypoglycemia on combined therapy (MtIBT + SGLT2i plus insulin Glargine at the dose of only 20 unites per day). After insulin discontinuation, no hypoglycemia was found. See Figures $3 a$ and $3 b$.

These examples demonstrate the impact of very low doses of insulin on hypoglycemia development. Those patients clearly had no insulin resistance (IR) at the time of CGM recording. Otherwise, it would be difficult to explain hypoglycemia development on a dose of insulin, which comprises only 0.42 to 0.83 units per hour on average.

While hypoglycemia in insulin-treated patients, even at very low such doses, did not come as a surprise and was apparently linked to insulin itself, it was unexpected to observe hypoglycemic events in non-insulin treated patients. Thus, in six patients (11.5\% of a total CGM group), despite the absence of hypoglycemic therapies like insulin, sulfonylurea, or Glinides, hypoglycemic events occurred.

Interestingly enough, in three patients, clinical manifestations of hypoglycemia were observed. Two of them were able to control the hypoglycemic attacks with food. In one patient (patient 1 in table 3), hypoglycemia was manifested by night perspirations. Since this patient did not link these signs to hypoglycemia, no intervention was done. All of the above raised our suspicion regarding the impact of SGLT2i per se on hypoglycemia development.

Figure 4 addresses patient 1 in Table 3 and demonstrates CGM chart of 66-year old patient, who suffered from T2DM for 10 years. Before CGM recording, this patient was treated constantly with Linagliptin $5 \mathrm{mg} /$ day and Metformin $2000 \mathrm{mg} /$ day. Recently Dapagliflozin $10 \mathrm{mg} /$ day was added to background therapy. The patient referred to our clinic because of newly appeared perspirations at nights. The CGM recording indicates prolonged hypoglycemic episodes, which most probably are the source of his newly appeared symptoms.
Avg SG: 129 mg/dL

Estimated $\mathrm{AlC}^{(1)}: \mathbf{6 . 1} \%$ calculated from SG values
Time in range: $\mathbf{3 0} \%$ Above $\mathbf{1 4 1} \mathbf{~ m g / d L}$

$65 \%$ in target range

$5 \%$ Below $70 \mathrm{mg} / \mathrm{dL}$

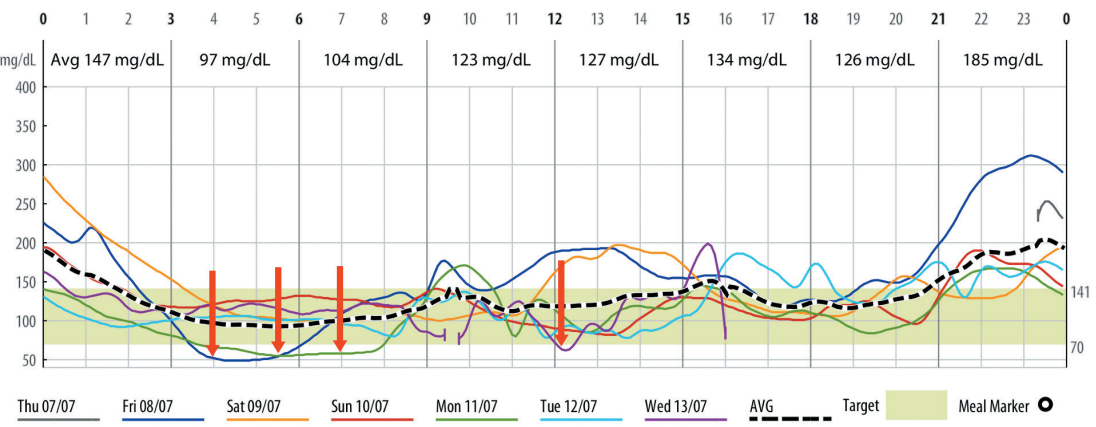

(c) 2016 Medtronic

Figure 3(A). Patient 4 in Table 3

Figure 5 demonstrates a CGM chart of 71-year old man suffering from T2DM for last 12 years (Patient 5 in table 3). He is constantly treated with Metformin $2550 \mathrm{mg} /$ day, Liraglutide $0.3 \mathrm{mg} /$ day and Empagliflozin $10 \mathrm{mg} /$ day. Clinical manifestations of hypoglycemia (5\% of time, 4 hours and 40 minutes) appeared after elevating the dose of Empagliflozin from $10 \mathrm{mg}$ to $25 \mathrm{mg} /$ day and were well-documented at CGM - recording. When the Empagliflozin dose was adjusted back to $10 \mathrm{mg} /$ day, hypoglycemia disappeared.

It has to be summarized, that in some patients hypoglycemia comprised up to $7 \%$ of TIR. The average Hypoglycemia TIR for all nine patients was 3,5\%, at some patients blood sugar got lower than low limit of sensor functional capability (less than $40 \mathrm{mg} \%$ ), three patients had clinical signs of low blood sugar, none of them on insulin therapy.
Prolonged hypoglycemia, time in range

7 hours, 20 minutes (5\%), minimal SG

$49 \mathrm{mg} \%$, in 69-year-old female. Before

adding Empagliflozin $10 \mathrm{mg} /$ day, the insulin dose was adjusted from 42 units

day in 4 injections to 20 units/day of

Glargine only; Liraglutide $0.3 \mathrm{mg} /$ day and Metformin $850 \mathrm{mg} \mathrm{x} \mathrm{3/day}$

Рисунок 3 (А). Пациент 4 в таблице 3: Длительная гипогликемия время в интервале 7 часов, 20 минут (5\%), минимальный SG 49 мг\%, у 69-летней женщины. Перед добавлением эмпаглифлозина 10 мг / день дозу инсулина корректировали

с 42 единиц / день в 4 инъекции до 20 единиц / день только

Glargine; Лираглутид 0,3 мг / день и метформин 850 мг х 3 / день

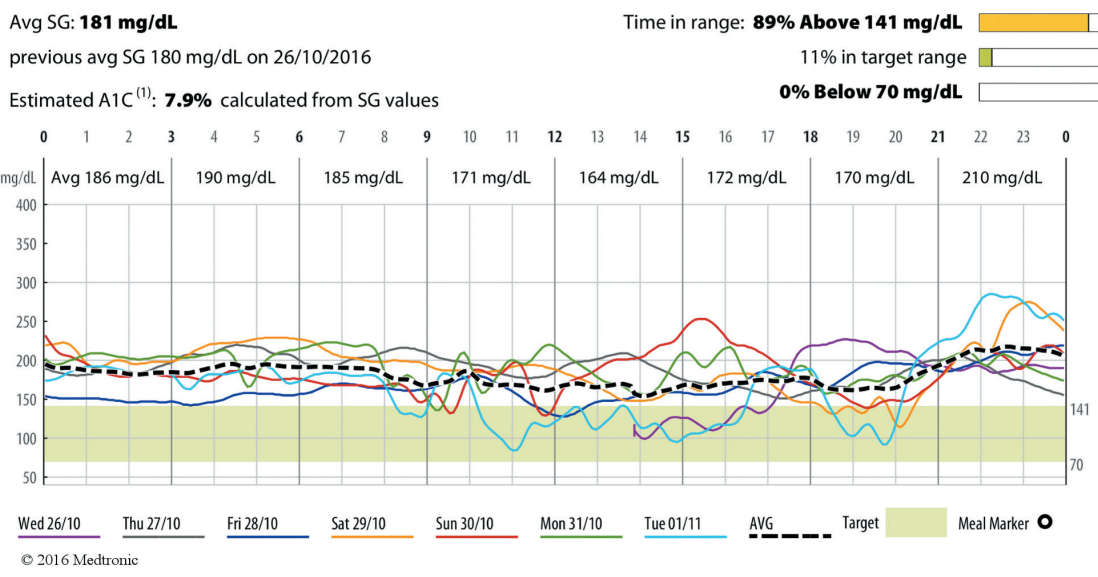

Ketosis development

Three patients (2.2\% of total cohort, 136 patients) demonstrated ketosis development according to the $\beta$-hydroxybutyrate measurement in the blood. All three received Empagliflozin (see Table 4).

First patient. A 59-year old man, suffers from a long-standing (20 years at least) untreated and uncontrolled T2DM. Ketosis appeared 3 weeks
Figure 3(B). Patient 4 in Table 3: Empagliflozin $10 \mathrm{mg} /$ day, Liraglutide $0.3 \mathrm{mg} /$ day and Metformin $850 \mathrm{mg}$ x 3/day continued. Insulin stopped. No hypoglycemia.

Рисунок 3 (В). Пациент 4 в таблице 3: эмпаглифлозин 10 мг/ день, лираглутид 0,3 мг / день и метформин 850 мг х 3 / день. Инсулин прекратился. Нет гипогликемии. 


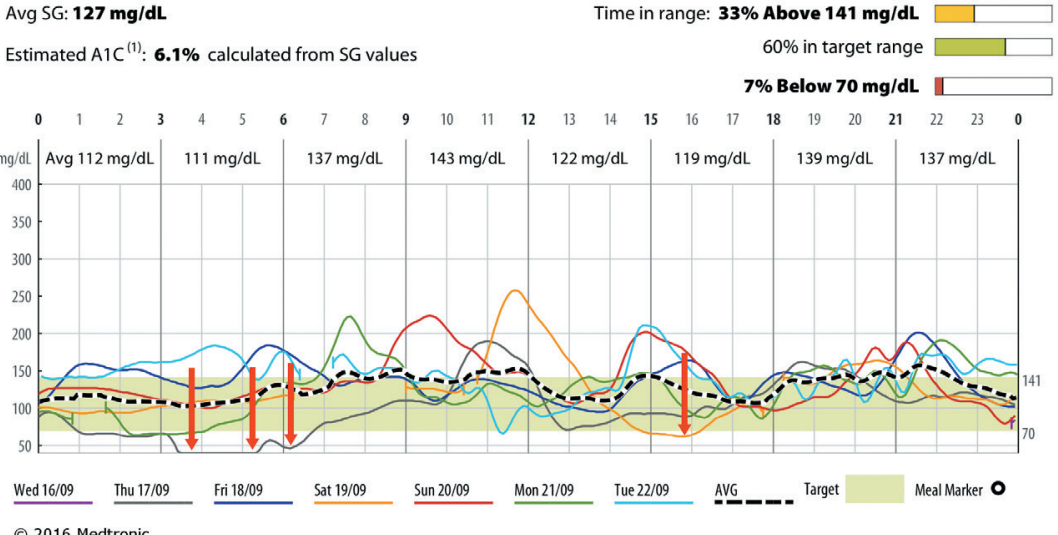

(c) 2016 Medtronic

Figure 4. Patient 1 in Table 3: Daytime and nighttime hypoglycemia (7\% of time, 9 hours and 15 minutes), in 66-year-old-man, who's suffered from diabetes for the last 10 years. Patient was treated constantly with Linagliptin 5mg/day and Metformin $2000 \mathrm{mg}$ /day. Recently Dapagliflozin $10 \mathrm{mg}$ /day was added. Complains of newly-appeared perspirations at nights.

Рисунок 4. Пациент 1 в таблице 3: дневная и ночная гипогликемия (7\% времени, 9 часов и 15 минут), у 66-летнего мужчины, который страдал от диабета в течение последних 10 лет. Пациента постоянно лечили линаглиптином 5 мг / сут и метформином 2000 мг / сут. Недавно был добавлен дапаглифлозин 10 мг / сут. Жалуется на вновь появившиеся поты по ночам.

\section{Avg SG: $110 \mathrm{mg} / \mathrm{dL}$}

Estimated $\mathrm{A} 1 \mathrm{C}^{(1)}: \mathbf{5 . 5} \%$ calculated from SG values

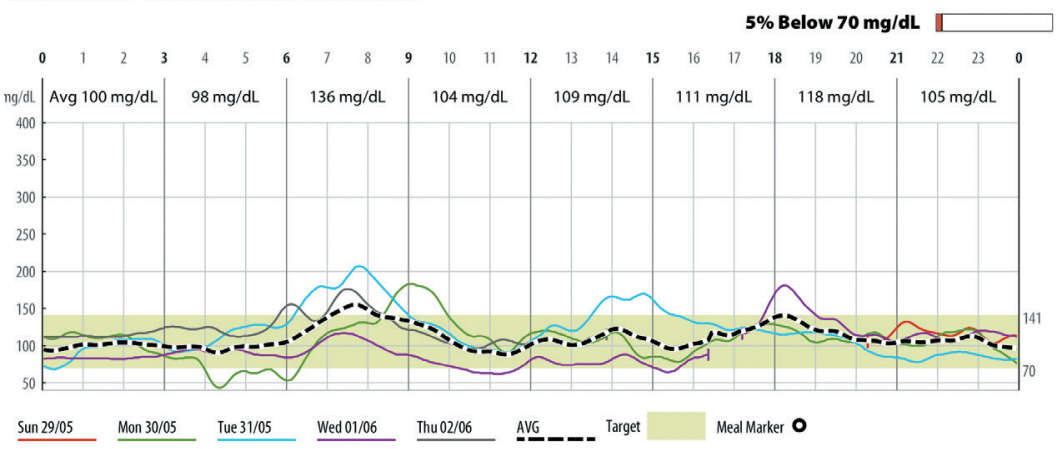

O 2016 Medtronic

Figure 5. Patient 5 in Table 3: Hypoglycemia in a 71-year-old patient who's had T2DM for the last 12 years. Clinical manifestations of hypoglycemia (5\% of time, 4 hours and 40 minutes) appeared after elevating Empagliflozin dose form $10 \mathrm{mg}$ to $25 \mathrm{mg}$ /day. Metformin $2550 \mathrm{mg}$ /day was continued. Patient reported clinically manifested hypoglycemia after first days of CGM recording. The Empagliflozin dose was adjusted back to $10 \mathrm{mg}$ /day and hypoglycemia disappeared.

Рисунок 5. Пациент 5 в Таблице 3: Гипогликемия у 71-летнего пациента, у которого была Т2DM в течение последних 12 лет. Клинические проявления гипогликемии (5\% времени, 4 часа и 40 минут) появились после повышения дозы эмпаглифлозина с 10 до 25 мг / день. Метформин 2550 мг / сут продолжался. Пациент сообщил о клинически выраженной гипогликемии после первых дней регистрации CGM. Доза эмпаглифлозина была доведена до 10 мг / сут, и гипогликемия исчезла.

after discharge from the hospital, where coronary artery bypass grafting was done. While hospitalized, this patient received a very intensive insulin therapy, 4-5 injections per day, at average daily doses of 5463 units (including basal insulin). After successful operation, patient started losing his weight due to low - carbohydrate diet and his insulin resistance rapidly disappeared. Few days before his discharge from the hospital his treatment was completely switched from insulin to Mt-IBT combination with a satisfactory glycemic control. In a trial to add on an Empagliflozin at the dose of $10 \mathrm{mg} /$ day only resulted in appearance of ketosis (Concentration of $\beta$-hydroxybutyrate $=2.1 \mathrm{mmol} / \mathrm{l}$ ). This patient most likely did not have time to develop clinical signs of KA and no manifestations of KA were noticed. He stopped Empagliflozin immediately in accordance to our recommendations and renewed it at the dose of $5 \mathrm{mg} /$ day after several weeks, when his $\beta$-hydroxybutyrate level returned to be normal. His glycemic control remained satisfactory that entire time.

Second patient. 70 - year old female, who have been suffered from T2DM for 38 years. From her past:

Patient have been treated by Multiple Daily Injections of Insulin (MDI) for 33 years. For the last 4 years - by CSII (insulin pump) therapy. Total daily insulin dose $(T D I)=30$ U/day. Subsequently, and according to our Gravicentric approach, insulin therapy was gradually stopped. Patient continued her treatment by Sitagliptin100 mg/ day, Metformin850 mg × 3/day. Empagliflozin $10 \mathrm{mg} /$ day was added later on. Her glycemic control was ideal, with estimated $\mathrm{HbA1C}$ of $6.1 \%$ on CGM. Two month later, in spite of the good glycemic control and without any insulin therapy, weakness and fatigue has appeared as a possible clinical sign of KA. Her $\beta$-hydroxybutyrate concentration revealed to be $2.0 \mathrm{mmol} / \mathrm{l}$.

She immediately stopped Empagliflozin and renewed it a month later, while her $\beta$-hydroxybutyrate levels returned to be normal. After $\mathrm{K}$ development, basal insulin of $10 \mathrm{U} /$ day was added. Diabetes control remained very good.

Third patient. A 66-year old female, who has been suffering from T2DM for the last 20 years. From her past: patient has been treated by Multiple Daily Injections (MDI) of Insulin for 10 years. She has been referred to our clinic due to a combination of uncontrolled diabetes, metabolic syndrome and recently discovered cancer of abdominal cavity (the primary source was unknown). She reacted very well to chemotherapy with disappearance of her abdominal masses. Nevertheless, her T2DM remained uncontrolled. Mt-IBT (Liraglutide) were started and insulin was completely withdrawn in several weeks. Empagliflozin $10 \mathrm{mg} /$ day was added later on.

She continued her follow - up at institute of oncology, whereas no cancer progression was noticed. She used to stop GLP-1 therapy while receiving the repetitive courses of chemotherapy because of gastro - intestinal side effects. At some point, on routine course of chemotherapy for stable cancer, which provoked anorexia and very low carbohydrate ( $\mathrm{CHO}$ ) consumption, she developed nausea and vomiting. Her $\beta$-hydroxybutyrate concentration was revealed to be $2.3 \mathrm{mmol} / \mathrm{l}$. Empagliflozin was immediately stopped. Subsequently, her $\beta$-hydroxybutyrate level returned to be normal and clinical signs disappeared.

Afterward, she was treated with Mt-IBT for years while her glycemic control remained satisfactory. Eventually, her diabetes reached the remission and her 
glycemic control remained good on Metformin only. Empagliflozin has never been renewed.

In order to substantiate our suspicion of SGLT2i provoked hypoglycemia, we studied all CGM recordings of all T2DM patients in our institute. Eleven CGM recordings of patients who passed the step-bystep therapeutic de-intensification from multiple insulin injections - up to insulin discontinuation (achievement of $\mathrm{HBA}_{1} \mathrm{C} \leq 7 \%$ was stated as a main criteria) were found. We used this data as a control. Of note, patients of both groups (study group and control group) were instructed and followed - up identically by the same medical staff and the same dietitian, with the very same recommendations regarding low - carbohydrate diet and physical activity. Both groups had an identical therapeutic approach with intention to lose weight in order to achieve the best glucose control and deintensification of therapy. Indeed, patients of both groups had reached a very good control with average $\mathrm{HBA}_{1} \mathrm{C}$ well below $7 \%$. There was no difference between degree of $\mathrm{HBA}_{1} \mathrm{C}$ reduction attained in both groups. It is particularly interesting to note the impressive difference in hypoglycemia occurrence in SGLT2i- treated group, routinely defined as Time-in-Range (TIR) below $70 \mathrm{mg} \%$. Given a study group was treated with Mt-IBT plus SGLT2, while control group - by Mt-IBT only, most probably, this phenomenon could be attributed to the effect of SGLT2 per se or specific effect of combination of SGLT2i with other glucose - lowering medications (mainlyMt-IBT), see Table 5 .

\section{DISCUSSION}

All study participants were treated according to our energetic (Gravicentric) concept and algorithm,[20-22] where patient's weight reduction is of the highest priority.

Given the fact that progressive weight gain is a "natural history" of T2DM,[23] it becomes clear that

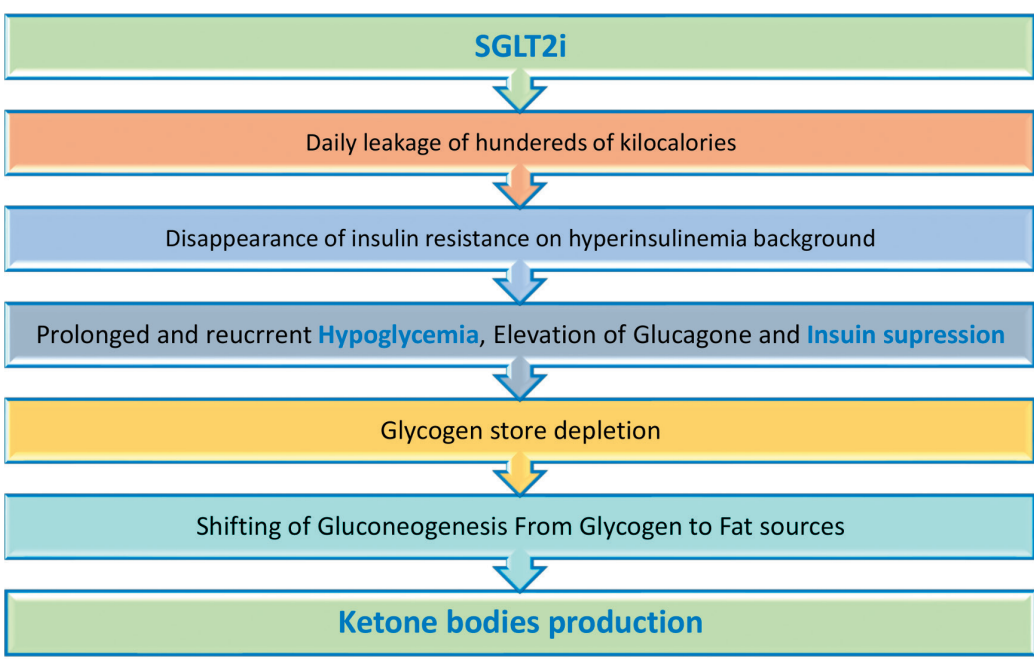

the so-called "weight-neutral" medications, like DPP4-i or AGI, are actually weight lowering. As a part of our concept, we refrain from using "proenergetic" medications (Sulfonylurea; Glinides; TZDs; high doses of insulin) in T2DM. That is why none of the participants of this study received these drugs. As for insulin, we managed to combine it with energy-wasting medications, like Metformin, GLP1 analogues; DPP4-i; SGLT2i etc. This is in order to cause therapeutic de-escalation and in some cases, even diabetes remission. The latter, according to our data, may comprise up to $13 \%$ and probably does not directly depend on disease duration.[24]

SGLT2i cause the daily leakage of hundreds of kilocalories [20, 27, 28], significantly improving metabolic health by restoring proper energy balance and facilitating body weight reduction, thus probably saving patients' lives. In the EMPA-REG study, the difference in the primary endpoint was mainly driven by the $38 \%$ relative risk reduction of $C V$ death. [1] While the therapeutic benefits of SGLT2i prevail over its side
Figure 6. The proposed mechanism of KA development through hypo-insulinemic hypoglycemia

Рисунок 6. Предполагаемый механизм развития КА через гипоинсулинемическую гипогликемию.

Table 1- Main results: tota cohort of $136 \mathrm{~T} 2 \mathrm{DM}$ patients * Of those, 1 patient received basal insulin

** Of those, 2 patient received basal insulin

Таблица 1 - Основные результаты: общая группа из

136 пациентов с T2DM

* Из них 1 пациент получал базальный инсулин;

** Из них 2 пациента получали базальный инсулин

\begin{tabular}{|c|c|c|c|c|c|c|}
\hline & \multicolumn{2}{|c|}{$\begin{array}{c}\text { Patients who received } \\
\text { Dapagliflozin } \\
\text { N (\%) }\end{array}$} & \multicolumn{2}{|c|}{$\begin{array}{l}\text { Patients who received } \\
\text { Empagliflozin } \\
\text { N (\%) }\end{array}$} & \multicolumn{2}{|c|}{$\begin{array}{c}\text { Total cohort with SGLT } 2 \\
\text { N (\%) }\end{array}$} \\
\hline Total $\mathbf{N}$ & \multicolumn{2}{|c|}{49} & \multicolumn{2}{|c|}{87} & \multicolumn{2}{|c|}{136} \\
\hline \multirow[t]{2}{*}{ Performed CGM } & \multicolumn{2}{|c|}{13} & \multicolumn{2}{|c|}{39} & \multicolumn{2}{|c|}{52} \\
\hline & $\begin{array}{c}\text { With } \\
\text { Hypoglycemia }\end{array}$ & $\begin{array}{c}\text { Without } \\
\text { hypoglycemia }\end{array}$ & $\begin{array}{c}\text { With } \\
\text { hypoglycemia }\end{array}$ & $\begin{array}{c}\text { Without } \\
\text { hypoglycemia }\end{array}$ & $\begin{array}{c}\text { With } \\
\text { Hypoglycemia }\end{array}$ & $\begin{array}{c}\text { Without } \\
\text { hypoglycemia }\end{array}$ \\
\hline Performed CGM & $\begin{array}{c}4 \text { (30.8 \%) } \\
\text { Of those, } \\
1 \text { patient } \\
\text { received basal } \\
\text { insulin }\end{array}$ & $9(69.2 \%)$ & $\begin{array}{l}5(12.8 \%) \\
\text { Of those, } \\
2 \text { patients } \\
\text { received basal } \\
\text { insulin }\end{array}$ & 34 (81.2 \%) & $9(17.3 \%)$ & $43(82.7 \%)$ \\
\hline $\begin{array}{l}\text { Ketosis developmen } \\
\text { according to } \\
\beta \text { - hydroxybutirate } \\
\text { measurement in } \\
\text { capillary blood }\end{array}$ & & & \multicolumn{2}{|c|}{$3(100 \%)$} & \multicolumn{2}{|c|}{$3(2.2 \%)$} \\
\hline
\end{tabular}


Table 2- Patients' basal characteristics and a comparison of the "Hypoglycemia" and "Non - hypoglycemia" groups * Basal $\mathrm{HbA}_{1 \mathrm{c}}$ - is the last laboratory $\mathrm{HbA}_{1 \mathrm{c}}$ performed before CGM recording; ** Estimated $\mathrm{HbA}_{\mathrm{lc}}$ - is a CGM-derived $\mathrm{HbA}_{1 \mathrm{c}}$; $* * * \Delta \mathrm{HbA}_{1 \mathrm{c}}=$ Basal $\mathrm{HbA}_{1 \mathrm{c}}-$ estimated $\mathrm{HbA}$

${ }^{* * * *} \mathrm{p}<0.01$

Таблица 2. Основные характеристики пациентов и сравнение групп

«Гипогликемия» и «Не гипогликемия»

* Базальный $\mathrm{HbA}$ последний лабораторный $\mathrm{HbA}_{1 \mathrm{c}}$, выполненный перед записью CGM;

** Расчетный $\mathrm{HbA}_{1 c}$ - это производный от CGM $\mathrm{HbA}_{1 \mathrm{c}}$;

$* * * \Delta \mathrm{HbA}_{1 \mathrm{c}}=$ Базальный $\mathrm{HbA}_{1 \mathrm{c}}$ - расчетный $\mathrm{HbA}_{1 \mathrm{c}}$; $* * * * \mathrm{p}<0,01$ effects, it seems to have become one of the most promising medication classes in T2DM.

As shown in Table 2, virtually all our patients were treated with a combination of Metformin and IncretinBased Therapy (Mt-IBT), while SGLT2i were usually added later on, as a third step. This therapeutic scheme was also applied in 14 (26.9\%) patients initially treated with multiple daily injections (MDI) of insulin. This approach allowed the de-intensification of insulin therapy in parallel with weight reduction. In these patients, short-acting insulin was stopped first, while SGLT2i were added at the stage of a single injection of basal insulin with substantially reduced total daily insulin (TDI) dose. With this kind of approach, further de-escalation of treatment has been successfully provided. Insulin was later withdrawn in 10 diabetes patients, comprising $7.4 \%$ of total cohort (136 T2DM patients) and $71.4 \%$ of all insulin-treated patients. Four patients (28.6\% of insulin-treated patients) remained on low-dose basal insulin therapy. This data, in concordance with other studies, showed an almost $50 \%$ reduction of insulin requirements when SGLT2i was added and could be attributed to a rapid disappearance of insulin resistance (IR), due to development of a negative energy balance.[27] Disappearance of IR already in first 24 hours of SGLT2i implementation was also shown in studies of De Fronzo.[18]
Later on, patients were divided into those whose CGM demonstrated hypoglycemia episodes (Group A) and those without hypoglycemia (Group B). In 3 (33\%) Group A patients and 11 (26.9\%) Group B patients, CGM was performed on basal insulin background (See Table 2). There was no difference between the groups in terms of age, sex, diabetes duration, and baseline HbA1c.

Time, spent in hypoglycemia range (Hypoglycemia TIR) was $3.53 \%$ on average in Group $A$ and with no hypoglycemia episodes in Group B. Our attempts to find predisposing factors for hypoglycemia revealed mean SG and estimated (sensor-derived) $\mathrm{HbA} 1 \mathrm{C}$ as the only significantly diverse parameters (see Figures $1 a$ and b).

This data comes in accordance with a well-known statement, which claims the stricter the diabetes control, the more likely the patient is to have hypoglycemia. $[28,29]$ This point was confirmed in our study, where the strictest glycemic control was linked to significantly higher hypoglycemia rates. Nevertheless, a control group (without SGLT2i) comparison indicates the impact of SGLT2 per se on hypoglycemia development (see Table 5).

While it was not surprising to observe hypoglycemia on a combination of Mt-IBT + SCLT2i with insulin (even at low doses of the last), it was unexpected to see hypoglycemia

\begin{tabular}{|c|c|c|c|c|}
\hline & $\begin{array}{c}\text { Total CGM } \\
\text { Cohort } \\
\text { N (\%) }\end{array}$ & $\begin{array}{c}\text { Group A } \\
\text { (Hypoglycemia) }\end{array}$ & $\begin{array}{c}\text { Group B } \\
\text { (Non-hypoglycemia) }\end{array}$ & $\begin{array}{c}\text { P } \\
\text { A vs. B }\end{array}$ \\
\hline Number of patients with CGM, n (\%) & $52(100)$ & $9(17.3)$ & $43(82.7)$ & NS \\
\hline Mean age, years & $59.4 \pm 10.6$ & $60.6 \pm 11.3$ & $58.8 \pm 10.7$ & NS \\
\hline Mean diabetes duration, years & $14.8 \pm 8.5$ & $13.1 \pm 3.9$ & $15.4 \pm 8.8$ & NS \\
\hline Males, n (\%) & $24(46.2)$ & $6(66)$ & $18(41.9)$ & NS \\
\hline Females, $n(\%)$ & $28(53.8)$ & $3(33)$ & $25(58.1)$ & NS \\
\hline Baseline $\mathrm{HbA}_{1 \mathrm{c}} \%$ & $8.2 \pm 1.3$ & $8.0 \pm 0.9$ & $8.2 \pm 1.4$ & NS \\
\hline Last Estimated $\mathrm{HbA}_{1 \mathrm{c}}$ on $\mathrm{CGM}^{* *}, \%$ & $6.8 \pm 1.1$ & $6.1 \pm 0.7$ & $6.9 \pm 1.0$ & 0.02 \\
\hline Last Average Sensor Glucose (SG), mg/dl & $148.4 \pm 30.7$ & $129.0 \pm 22.5$ & $151.9 \pm 30.6$ & 0.04 \\
\hline$\Delta \mathrm{HbA}_{\mathrm{lc}}{ }^{* * * *}$; \% & $1.1 \pm 1.3$ & $1.7 \pm 0.67$ & $1.1 \pm 1.5$ & 0.47 \\
\hline BMI at admission to the clinic $(\mathrm{kg} / \mathrm{cm} 2)$ & $34.9 \pm 6.2$ & $34.8 \pm 3.7$ & $35.1 \pm 5.3$ & NS \\
\hline BMI at the end of the study**** & $31.3 \pm 4.1$ & $31.1 \pm 4.2$ & $31.5 \pm 4.6$ & NS \\
\hline Received Metformin; n (\%) & $52(100)$ & $9(100)$ & $43(100)$ & NS \\
\hline Received DPP-4-i, n (\%) & $9(17.3)$ & $1(11.0)$ & $8(18.6)$ & NS \\
\hline Received GLP-1 analogues, $n$ (\%) & $43(82.7)$ & $8(89.0)$ & $35(81.4)$ & NS \\
\hline Received Basal Insulin at the time of CGM, $n(\%)$ & $14(26.9)$ & $3(33.3)$ & $11(26.9)$ & NS \\
\hline Insulin was subsequently withdrawn, n (\%) & $10(19.2)$ & $3(33.3)$ & $7(16.3)$ & NS \\
\hline
\end{tabular}


on MT-IBT + SGLT2i combination only, knowing that neither Metformin, nor IBT per se, or combined, result in any significant hypoglycemia.[24, 30, 31]

Apparently, more frequent and prolonged hypoglycemia events (as shown on CGM) could be attributed to SGLT2i itself or to the specific effect of combining SGLT2i with IBT and Metformin in particular, knowing that the last suppresses gluconeogenesis, thus probably aggravating the process of recovery from hypoglycemia.

Wesuggestanexplanationforthisphenomenonfroman energy-balance position. Hypoglycemia development can be addressed to a rapid disappearance of insulin resistance (IR) in SGLT2i-treated patients, which in turn is the result of constant energy leakage. It could be easily demonstrated in practice by a reduction of insulin demands in our patients. First, with these therapies, insulin-treated patients were able to reduce their doses dramatically, most of them up to complete withdrawal. In addition, as shown on the CGM recordings, even at very low doses of basal insulin and in spite of insulin dose adjustments, patients rapidly became normoglycemic and even hypoglycemic. These findings come in concordance with other works, showing insulin resistance disappearance and propensity to diabetes remission on very low-calorie diets and/or IBT.[32-34] In our opinion, all this is a convincing confirmation of IR-disappearance on energy-wasting therapy.

Providing most T2DM patients suffer from hyperinsulinemia in parallel with $I R,[35]$ one may suggest rapid IR disappearance may cause hypoglycemia. While most hypoglycemia discovered by CGM seems to be silent and occurring mainly at nights, there were three cases of clinically overt hypoglycemia in our patients (none of them on insulin). The silent night hypoglycemia may potentially be very dangerous given patients' unawareness and its prolonged duration: up to $7 \%$ of time-in-range in some patients on CGM recordings (see Table 3). From the pathophysiological point, recurrent and prolonged hypoglycemia results in three main compensatory reactions: first, enhancement of glucagon secretion; second, the suppression of insulin secretion; and third, the mobilization of glycogen from depot and augmentation of gluconeogenesis.

Interestingly enough, Glucagon seems to be a major player. Studies in T1DM with insulin withdrawal, suggest glucagon has an important role in the pathogenesis of ketoacidosis, since neither severe hyperglycemia nor hyperketonemia developed during suppression of glucagon with somatostatin.[36]

\section{A link to ketosis (K) and ketoacidosis (KA)}

The term 'Euglycemic Diabetic Ketoacidosis' was recently introduced, as the clinical experience of SGLT2i implementation grows.[4] Nevertheless, the American Association of Clinical Endocrinologists \& American College of Endocrinology (AACE/ACE) considers "Euglycemic" diabetic ketoacidosis (DKA) a misleading term and instead recommends the use of "DKA with lower-than-anticipated glucose levels".[5] However, the question of how low glucose may still be, causing KA development seems to remain unanswered. In this paper, we intentionally avoid
Table 3- Characteristics of patients with CGM-proved

hypoglycemia on SGLT2i

Таблица 3 - Характеристики пациентов с

подтвержденной CGM гипогликемией на SGLT2i

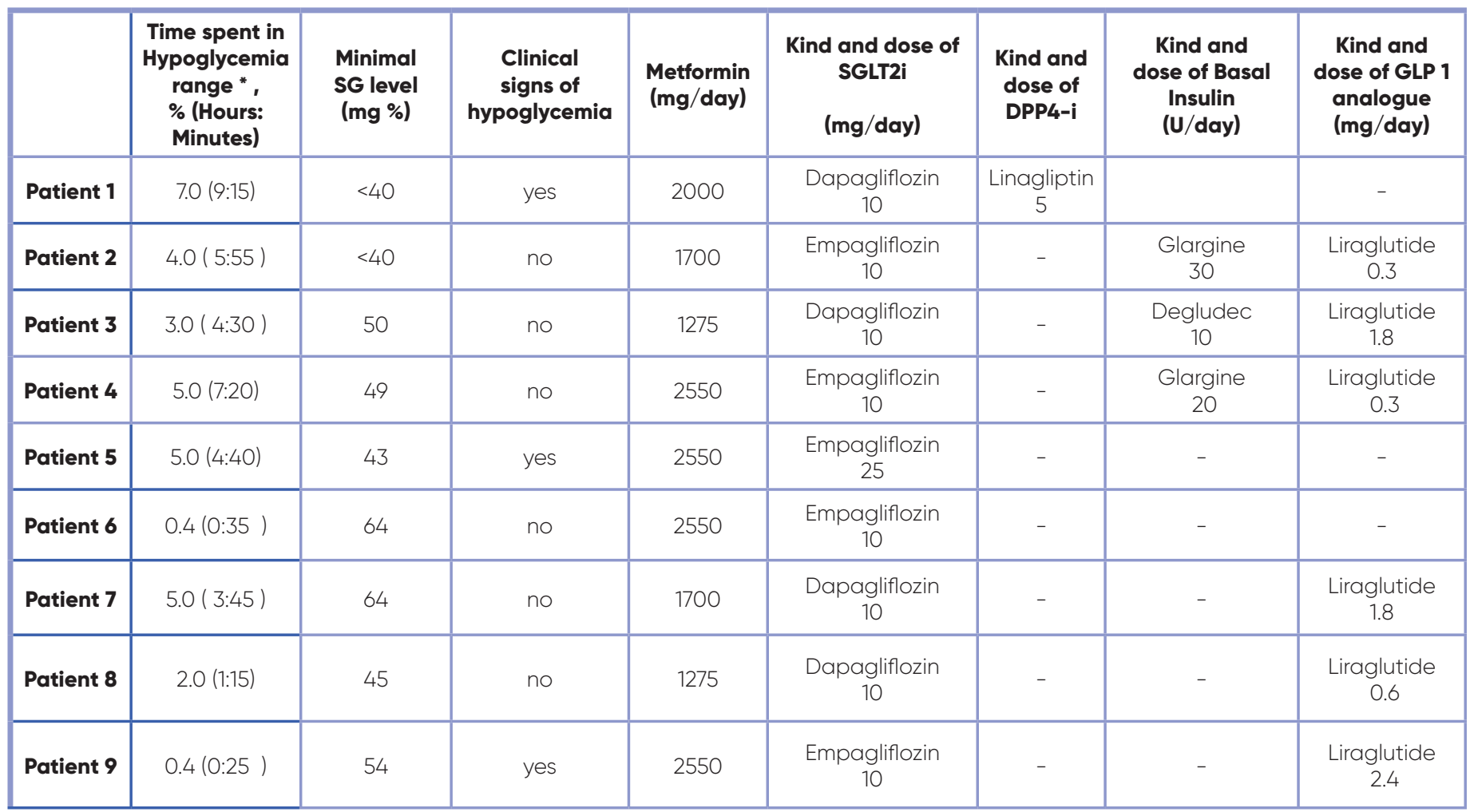

${ }^{*}$ Hypoglycemia was defined as reduction of SG (Sensor Glucose) below $70 \mathrm{mg} \%$. 
the term 'Diabetic Ketoacidosis' or DKA, thus emphasizing the possibility of this kind of ketosis $(K)$ and ketoacidosis (KA) even in non-diabetes patients.

In our study, three (2.2\%) of 136 patients were found to develop $\mathrm{K}$, as was indicated by repeatedly elevated levels of capillary blood $\beta$-hydroxybutyrate. Interestingly enough, two out of three patients had mild clinical signs such as nausea, loss of appetite, general weakness, and fatigue. These signs and symptoms could easily be attributed to other pathologies, like gastro-intestinal viral infections, except for the finding of elevated ( $\geq 2.0 \mathrm{mmol} / \mathrm{l})$ $\beta$-hydroxybutyrate concentration in capillary blood.

Unfortunately, recently published warning of Israeli Ministry of Health [53] confirmed our concerns regarding particularly high incidence of KA (67 cases) on SCLT2i therapy background, (41 cases were reported in 2017). All of them required hospitalization, while two patients died. In May 2015, the US Food and Drug Administration (FDA) sent out a warning to alert the healthcare community about the potential for "euglycemic ketoacidosis " in patients with type 2 diabetes who are using SGLT2 inhibitors.[4] The warning ensued after 20 acidosis cases were reported to the FDA Adverse Event Reporting System database between March 2013 and June 6, 2014. The risk was particularly high in patients undergoing anesthesia for surgery procedures. Nevertheless, subsequent to this FDA warning, the results of the EMPA-REG trial did not find any increased risk for KA with Empagliflozin compared with placebo.[1]

While even low doses of exogenous insulin may effectively prevent $\mathrm{K}$ and $\mathrm{KA}$ development, it is not surprising, that many patients develop this complication particularly after insulin withdrawal. Interestingly, in analysis of Ogawa et al, in six (21.4\%) out of 28 patients who developed KA, the cessation of insulin or insulin secretagogue was suggested as a possible contributing factor. In $12(41.8 \%)$ patients the reason was not found, while in most other patients, starvation and appetite loss as well as low-carbohydrate diet were the trigger.[13] Accordingly, in all three of our patients who subsequently developed ketosis, insulin had been stopped earlier because of very good glucose control and absence of the necessity for insulin therapy continuation (Table 4), thus elevating the suspicion of Hypoglycemic-Hypoinsulinemic ketosis.

Development of $\mathrm{K}$ and $\mathrm{KA}$ on low-carbohydrate (CHO) diet combined with SGLT2i is especially interesting since in this case, acceleration of urinary glucose excretion by a SGLT2 inhibitor, would lead to a no-carbohydrate-available hypoglycemia state and a completely-insulin-deficient
Таблица 4. Характеристика пациентов с кетоацидозом (КА)
Table 4. Characteristics of patients with ketoacidosis (KA)

\begin{tabular}{|c|c|}
\hline & Case 1 \\
\hline Age, years & 59 \\
\hline Sex & Male \\
\hline Diabetes duration, years & 20 \\
\hline $\begin{array}{c}\text { Time from beginning of } \\
\text { treatment with SGLT2i to KA } \\
\text { development }\end{array}$ & 1.5 months \\
\hline Combined therapy & $\begin{array}{l}\text { Metformin (850 mg × 3/day) } \\
\text { Liraglutide (1.2 mg/day) }\end{array}$ \\
\hline SGLT2i & Empagliflozin (10 mg/day) \\
\hline $\begin{array}{c}\text { Concentration of } \beta \text {-hydroxy- } \\
\text { butyrate, } \mathrm{mmol} / \mathrm{L}\end{array}$ & 2.1 \\
\hline Possible trigger & Stopped insulin therapy \\
\hline Comments & $\begin{array}{l}\text { Long-standing untreated and } \\
\text { uncontrolled T2DM. Ketosis } \\
\text { appeared } 3 \text { weeks after dis- } \\
\text { charge from the hospital, where } \\
\text { coronary artery bypass grafting } \\
\text { was done. No clinical signs of } \\
\text { KA. Stopped Empagliflozin and } \\
\text { renewed it after several weeks. } \\
\text { Diabetes control remained } \\
\text { satisfactory }\end{array}$ \\
\hline
\end{tabular}


condition, resulting in exacerbating ketosis and finally in ketoacidosis.[37] In this case report, authors describe a 32-year-old diabetes woman who developed severe KA on SGLT2i combined with low-carbohydrate diet. Though authors were unable to confirm hypoglycemia, they found urinary C-peptide, which was undetectable at admission, increased up to $40.2 \mu \mathrm{g} /$ day after initiation of a diet containing $210 \mathrm{~g}$ carbohydrate/day. Clearly, the patient's endogenous insulin secretion was suppressed, most likely by silent prolonged hypoglycemia, and rapidly recovered after returning to a normal diet. This report may indicate the common pathway of Hypoglycemic-Insulinopenic ketosis and KA development in SGLT2i treated patients. In spite of a quite different pathogenesis of T2DM and Addison's disease, both of them most probably demonstrate the same Hypoinsulinemic hypoglycemia mechanism as a cornerstone of ketosis and KA development.

As insulinopenia and hypoglycemia are classic signs of Addison's disease, it seems interesting to discover numerous reports regarding $\mathrm{KA}$ as a presenting sign of a new-onset Addison's. One of them describes KA development in type 1 diabetes mellitus patient with newly - diagnosed Addison's, accompanied by a recurrent and severe hypoglycemia before hospital admission and even during hospitalization.[38] In another patient, without diabetes, ketoacidosis was a presenting sign of an inadequately treated Addisonian crisis. In this patient, prolonged starvation and absence of counter-regulation probably resulted in Hypoinsulinemic hypoglycemia and KA development. [39] Interestingly, hypoglycemia and ketoacidosis were a presenting sign in almost 30\% of children with newonset Addison's disease[40].

Starvation-provoked ketoacidosis may also serve as analogue of no-carbohydrate-available hypoglycemicinsulinopenic state, with complete insulin deficiency and resulting $K$ and $K A$, which is probably quite similar to what we observe on SGLT2i therapy.

Under normal circumstances, with optimal glucose availability and normal insulin secretion, glycolysis generates pyruvate, which enters the citric acid cycle for energy generation by the production of ATP. In any lowglucose-availability situation, due to either starvation or insulin deficiency, or both, as well as glucose leakage on SGLT2i, there is a deficiency of pyruvate entering the citric acid cycle due to a depletion of glycogen stores. Alternative sources of energy in such circumstances are provided by the generation of acetyl-CoA from betaoxidation of fatty acids. The amount of the produced acetyl-CoA may exceed the capacity of the citric acid cycle, resulting in the generation of $\beta$-Hydroxybutyrate, acetoacetate, and acetone.[41-45]

The proposed mechanism of KA development through Hypoinsulinemic hypoglycemia is reflected in Figure 6.

Interestingly, we recently (after study closure) observed the 4 th case of severe KAina 51-year old diabetes patient from our study who developed this complication with need for lung ventilation in ICU. His venous blood $\mathrm{pH}$ has reached 7.022 at admission, while no hyperglycemia was observed. This patient started Empagliflozin $10 \mathrm{mg} /$ day added to Mt-IBT five months before KA development. He received the kit for $\beta$-Hydroxybutyrate measurement but unfortunately have ignored our recommendation to check it concentrations. Four months later he developed viral infection with subsequent pneumonia. His appetite was low and he started losing weight rapidly. Clearly, there was a necessity to stop Empagliflozin, but unfortunately, his family physician didn't discontinue this medication timely. Immediately after this, he developed severe KA and was hospitalized in ICU. Empagliflozin was stopped. His venous blood $\mathrm{pH}$ at discharge was 7.42. Given severe infections may cause exacerbation of IR, relative, but not absolute insulin deficiency [46], we attribute KA development in this patient to the same proposed pathophysiological mechanism (SGLT2ienhanced negative energy balance - hypoglycemia Hypoinsulinemia - KA).

During starvation, there is significant elevation of glucagon concentrations, together with low insulin, the later also appears to be biologically inactive and rapidly disintegrating.[47] Unger et al. report the results of glucose-insulin-glucagon-free fatty acids (FFA) changes in eight volunteers during and after 72-hours of starvation. Remarkably, participants demonstrated hypoglycemic or near-hypoglycemic values, their glucose concentration declined progressively during starvation to a mean level of $54.0 \mathrm{mg} \%$ on the third day, and in three individuals, values of $45 \mathrm{mg} \%$ or less were observed during the fast. FFA levels went up sharply, more than threefold compared to pre-starvation levels. [47] Clearly, all of the above predisposes to ketoacidosis development. Our suggestion, the pathophysiological changes in well-controlled T2DM patient continuing the unadjusted full-dose SGLT2i therapy may be quite similar to above-mentioned condition. Interestingly, all three our patients, who later developed ketosis, were well-controlled, making their insulin treatment unnecessary. Therefore, in the SGLT2i case, it is probably Hypoinsulinemic hypoglycemic ketosis and ketoacidosis development that is discussed, rather than "euglycemic ketoacidosis".

As for type 1 diabetes, patients showed clear and statistically significant propensity to hypoglycemia development when Empagliflozin was added on stable insulin doses. However, no ketosis elevation was observed, most probably because patients were further allowed to reduce the insulin doses on flexible insulin regimen, thus avoiding hypoglycemia.[48] Interestingly enough, in another study addressing type 1 diabetes patients, high fasting beta-hydroxybutyrate levels were observed in one patient on Empagliflozin $2.5 \mathrm{mg}$ and one patient on Empagliflozin $25 \mathrm{mg}$ during routine safety laboratory monitoring at week 4, albeit, these patients were asymptomatic.[49] Finally, recent DEPICT study clearly demonstrated SGLT2i - induced elevation of KA frequency. [50]

In our opinion, glycogen stores depletion is an important condition, necessary for $\mathrm{K}$ and KA development. In fact, ketosis would not appear until an opportunity to easily mobilize sufficient glucose from the depot would 
Table 5. A comparison of Group A and Control Group reveals the highly significant difference in the percent of time spent in hypoglycemia range (TIR) in SGLT2i-treated patients.

${ }^{*}$ Basal $\mathrm{HbA}_{1 c}$ - is the last laboratory $\mathrm{HbA}_{1 \mathrm{c}}$ performed before CGM recording;

** Estimated $\mathrm{HbA}_{1 c}$ - is a CGMderived $\mathrm{HbA}_{1}$;

*** The BMI reduction was highly significant in both groups, $\mathrm{p}<0.01$

Таблица 5. Сравнение группы А и контрольной группы показывает очень значительную разницу в процентах времени, проведенного в диапазоне гипогликемии (TIR) y пациентов, получавших SGLT2i * Базальный $\mathrm{HbA}$ - последний лабораторный $\mathrm{HbA}$ выполненный перед записью CGM;

** Расчетный $\mathrm{HbA}$ - это производный от CGM HbA *** Снижение ИМТ было высоко значимым в обеих группах, $\mathrm{p}<0,01$ present itself. Only after glycogen depletion, which apparently depends on time spent in hypoglycemia, gluconeogenesis shifts from glycogen to fat sources. Free fatty acids (FFA) concentration rises and ketone production begins. Preserved glycogen stores may explain why our hypoglycemia-proved patients kept normal levels of $\beta$-hydroxybutyrate. This may also explain why patients undergoing prolonged fasting before surgeries are at maximal risk. It is not surprising therefore, that the PRAC recommends temporarily stopping SGLT2i in patients hospitalized for major surgical procedures or due to serious illness.[14]

Our findings may have valuable practical implementations. First of all, we recommend considering SGLT2i dose adjustment when patient approaches $\mathrm{HbA} 1 \mathrm{c}$ of $7 \%$ or less, as to prevent the development of hypoglycemia. Measuring $\beta$-hydroxybutyrate is helpful, since even subclinical propensity to ketoacidosis may reflect an elevation of FFA with their deteriorating effect on the heart. Pilz et al, showed that FFA levels independently predict all-cause and cardiovascular mortality in subjects with angiographic coronary artery disease [51].

We discovered more frequent than previously reported hypoglycemia rates in SGLT2i treated T2DM patients. After excluding three patients with hypoglycemia events on insulin therapy, our data demonstrate hypoglycemia rate of $11.5 \%$ of the total 52 patient's group, who performed CGM. Silent (night) hypoglycemia, is a well-known risk factor for cardiovascular events, silent myocardial infarction (MI) and stroke. The EMPA-REG study did not include silent $\mathrm{MI}$ in the primary analysis for major adverse cardiovascular events (MACE). Only about half of the patients were screened for silent MI. When this was included in the primary analysis, the primary MACE endpoint still demonstrated non-inferiority but no longer showed superiority as compared to placebo. No significant difference was also observed between Empagliflozin and placebo for non-fatal stroke [52]. Could it be attributed to silent hypoglycemia in Empagliflozin arm? So far, the question remains unanswered.

\section{Study limitations}

We were unable to track the possible link between time of exposure to SGLT2i therapy and hypoglycemia/ KA development. Theoretically, it seems plausible this kind of dependence may exist, since glycogen stores depletion is a time-consuming process. We were also unable to discover KA development in patients with CGM-proved hypoglycemia. It is likely they simply have not had enough time for glycogen store depletion. Additional studies are required to evaluate this suggestion.

\section{SUMMARY}

To our knowledge, this is the first study investigating real-life rates of hypoglycemia and ketosis with the help of such precise tools as CGM and capillary blood

\begin{tabular}{|c|c|c|c|}
\hline & $\begin{array}{c}\text { Group A } \\
\text { (Hypoglycemia) }\end{array}$ & $\begin{array}{c}\text { Control group } \\
\text { (Mt-IBT only), n=11 }\end{array}$ & $\begin{array}{c}\text { P } \\
\text { A vs. control }\end{array}$ \\
\hline Number of patients with CGM, $n$ & 9 & 11 & NS \\
\hline Mean age, years & $60.6 \pm 11.3$ & $59.2 \pm 8.3$ & NS \\
\hline Mean diabetes duration, years & $13.1 \pm 3.9$ & $14.3 \pm 6.8$ & NS \\
\hline Males, n (\%) & $6(66)$ & $7(63.6)$ & NS \\
\hline Females, $n(\%)$ & $3(33)$ & $4(36.4)$ & NS \\
\hline Baseline $\mathrm{HbA}_{\mathrm{fc}^{\prime}} \% *$ & $8.0 \pm 0.9$ & $8.2 \pm 1.7$ & NS \\
\hline Last Estimated $\mathrm{HbA}_{1 \mathrm{c}}$ on $\mathrm{CGM}^{* *}, \%$ & $6.1 \pm 0.7$ & $6.6 \pm 0.45$ & NS \\
\hline Last Average Sensor Glucose (SG), mg/dl & $129.0 \pm 22.5$ & $142.6 \pm 30.6$ & NS \\
\hline Time in Hypoglycemia Range (\%) & $3.5 \pm 2.3$ & $0.4 \pm 1.4$ & 0.0005 \\
\hline BMI at admission to the clinic $(\mathrm{kg} / \mathrm{cm} 2)$ & $34.8 \pm 3.7$ & $34.9 \pm 5.3$ & NS \\
\hline BMI at the end of the study*** & $31.1 \pm 4.2$ & $32.3 \pm 5.8$ & NS \\
\hline Received Metformin; n (\%) & $9(100)$ & $11(100)$ & NS \\
\hline Received DPP-4-i, n (\%) & $1(11.0)$ & 0 & NS \\
\hline Received GLP-1 analogues, $n$ (\%) & $8(89.0)$ & $11(100)$ & NS \\
\hline Received SGLT2i & $9(100)$ & 0 & \\
\hline
\end{tabular}


$\beta$-hydroxybutyrate measurement in T2DM patients treated with SGLT2i. Surprisingly, hypoglycemia rates (11.5\% of the total 52 patient's group, who performed CGM) were revealed to be higher than previously reported. Moreover, in a significant proportion of patients these side effects were clinically silent. Additionally, combining SGLT2i with basal insulin (even at very low such doses) frequently resulted in silent hypoglycemia, confirming our proposal regarding IR disappearance on a negative-energy-balance background. We suggest a link between prolonged hypoglycemia and ketosis development. The outcome seems to be exposure-and-dose-dependent, relying on glycogen stores depletion. Diabetologists and general practitioners (GP) should be aware of these effects.

Despite the fact that the benefits of SGLT2 inhibitors continue to outweigh their risks in T2DM treatment, we strongly recommend to preventively discontinue SGLT2i, or at least to adjust its dose, in severely ill and/or hospitalized patients, as well as in patients undergoing prolonged fasting. Considering dose adjustment is also recommended in patients approaching $\mathrm{HbA1c}$ levels of $\leq$ $7 \%$. Routine measurement of blood ketones and regular performance of CGM recordings are advised.

\section{CONCLUSIONS}

More frequent than previously reported rates of hypoglycemia and ketosis were discovered in patients taking SGLT2 inhibitors. Pathophysiological link between

\section{REFERENCES}

1. Zinman B, Wanner C, Lachin JM, et al. Empagliflozin, Cardiovascular Outcomes, and Mortality in Type 2 Diabetes. N Engl J Med. 2015;373(22):2117-28. doi: 10.1056/NEJMoa1504720

2. Wilding Clifford Bailey Una Rigney Betina Blak Wendy Beekman Cathy Emmas J. Glycated Hemoglobin, Body Weight and Blood Pressure in Type 2 Diabetes Patients Initiating Dapagliflozin Treatment in Primary Care: A Retrospective Study. Diabetes Ther. 2016;7(4):695-711. doi: 10.1007/s13300-016-0193-8

3. Food and Drug Administration. FDA Drug Safety Communication: FDA strengthens kidney warnings for diabetes medicines canagliflozin (Invokana, Invokamet) and dapagliflozin (Farxiga, Xigduo XR) [Internet]. 2016.

4. Announcement S. FDA warns that SGLT2 inhibitors for diabetes may result in a serious condition of too much acid in the blood. Vol. 2014. 2015.

5. Handelsman Y, Henry RR, Bloomgarden ZT, et al. American Association of Clinical Endocrinologists and American College of Endocrinology Position Statement on the Association of Sglt-2 Inhibitors and Diabetic Ketoacidosis. Endocr Pract. 2016;22(6):75362. doi: 10.4158/EP161292.PS

6. Announcement S. FDA Drug Safety Communication: FDA revises labels of SGLT2 inhibitors for diabetes to include warnings about too much acid in the blood the two conditions is assumed. More studies are needed to confirm our hypothesis.

\section{LIST OF ABBREVIATIONS}

AACE/ACE: American Association of Clinical Endocrinologists \& American College of Endocrinology

CGM: Continuous Glucose Monitoring

CSII: Continuous Subcutaneous Insulin Infusion

CHO: Carbohydrate

DKA: Diabetic Ketoacidosis

DPP-4: Dipeptidyl Peptidase 4

EMA: European Medical Agency

FFA: Free Fatty Acids

GLP-1: Glucagon-Like Peptide-1 Analogue

GP: General Practitioners

HbA1c: Hemoglobin A1C

$\mathrm{KA}$ : Ketoacidosis

$\mathrm{K}$ : Ketosis

MACE: Major Adverse Cardiovascular Events

MDI: Multiple Daily Injections

MI: Myocardial Infarction

Mt-IBT: Metformin Plus Incretin-Based Therapy

OAD: Oral Antidiabetic Drugs

PRAC: Pharmacovigilance Risk Assessment Committee

IR: Insulin Resistance

SG: Sensor Glucose

SGLT2i: Sodium-Glucose Co-Transporter 2 Inhibitors

T1DM: Type 1 Diabetes

T2DM: Type 2 Diabetes Mellitus

TIR: Time-In-Range.

and serious urinary tract infections [Internet]. FDA Drug Safety Communication. 2015. p. 2-4.

7. Nainggolan L. EMA Probes Link with Diabetes Drug Canagliflozin, Toe Amputation [Internet]. Medscape Medical News.

8. Geerlings S, Fonseca V, Castro-Diaz D, et al. Genital and urinary tract infections in diabetes: Impact of pharmacologically-induced glucosuria. Diabetes Res Clin Pract. 2014;103(3):373-81. doi: 10.1016/j. diabres.2013.12.052

9. Neal B, Perkovic V, Mahaffey KW, et al. CANVAS Programme Collaborative Group. Canagliflozin and Cardiovascular and Renal Events in Type 2 Diabetes. N Engl J Med. 2017;377(7):644-57.

10. FDA warns about rare occurrences of a serious infection of the genital area with SGLT2 inhibitors for diabetes. 29.08.2018, available at https://www.fda. gov/Drugs/DrugSafety/ucm617360.htm

11. Singh, J., Williamson, S.K., Malani, A.K. and Harewood, G.C., 2017. Risk of Diabetic Ketoacidosis after Initiation of an SGLT2 Inhibitor. NEJM, 376;2300, June 8, 2017

12. Rosenstock J, Ferrannini E. Euglycemic diabetic ketoacidosis: A predictable, detectable, and preventable safety concern with sglt2 inhibitors. Diabetes Care. 2015;38(9):1638-42. doi: 10.23371 dc15-1380 
13. Ogawa W, Sakaguchi K. Euglycemic diabetic ketoacidosis induced by SGLT2 inhibitors: Possible mechanism and contributing factors. J Diabetes Investig. 2016;7(2):135-8. doi: 10.1111/jdi.12401

14. Agency EM. SGLT2 inhibitors: PRAC makes recommendations to minimise risk of diabetic ketoacidosis: Healthcare professionals should be aware of possible atypical cases. Vol. EMA/100751. 2016. p. 1-2.

15. Administration USF and D. FDA Drug Safety Communication: FDA revises label of diabetes drug canagliflozin (Invokana, Invokamet) to include updates on bone fracture risk and new information on decreased bone mineral density [Internet]. 2015.

16. Novikov A, Vallon V. Sodium glucose cotransporter 2 inhibition in the diabetic kidney. Curr Opin Nephrol Hypertens. 2016;25(1):50-8. doi: 10.1097/ MNH.0000000000000187

17. Scheen AJ. SGLT2 inhibition: efficacy and safety in type 2 diabetes treatment. Expert Opin Drug Saf. 2015;14(12):1879-904. doi: 10.1517/14740338.2015.1100167

18. DeFronzo RA, Norton L, Abdul-Ghani M. Renal, metabolic and cardiovascular considerations of SGLT2 inhibition. Nat Rev Nephrol. 2017;13(1):11-26. doi: 10.1038/nrneph.2016.170

19. Zurek AM, Yendapally R, Urteaga EM. A Review of the Efficacy and Safety of Sodium-Glucose Cotransporter 2 Inhibitors: A Focus on Diabetic Ketoacidosis. Diabetes Spectr. 2017;30(2):137-42. doi: $10.2337 / d s 16-0030$

20. Levit S., Dzeranova, Larisa K., \& Philippov, Y. I. (2013). The Gravicentric Concept in type 2 Diabetes: practical implementation. Obesity and Metabolism, (3), 50-54. https://doi.org/10.14341/2071-8713-3865

21. Levit S, Giveon S, Philippov Yl, et al. Type 2 diabetes therapeutic strategies: Why don't we see the "ELEPHANT" in the room? Diabetes Mellit. 2016;19(4):341-9. doi: 10.14341/DM7077

22. Levit S, Philippov YI, Gorelyshev AS. Type 2 diabetes mellitus: Time to change the concept. Diabetes Mellit. 2013;16(1):91-102.

23. UK Prospective Diabetes Study Group (34). Effect of intensive blood-glucose control with metformin on complications in overweight patients with type 2 diabetes. BMJ. 1998;352(Ukpds 34):703-13. doi: 10.1016/S0140-6736(98)07037-8

24. Levit S, Giveon S, Ginossar G, et al. Occurrence of Hypoglycemia in Type 2 Diabetes Patients in a Perspective of a New Therapeutic Paradigm. In: Diabetes Technology \& Therapeutics. 2016. p. A39-A40.

25. Tahrani, A. A., Barnett, A. H., \& Bailey, C. J. (2013). SGLT inhibitors in management of diabetes. The
Lancet Diabetes \& Endocrinology, 1(2), 140-151. https://doi.org/10.1016/S2213-8587(13)70050-0

26. Abdul-Ghani, M. A., Norton, L., \& DeFronzo, R. A (2011). Role of Sodium-Glucose Cotransporter 2 (SGLT 2) Inhibitors in the Treatment of Type 2 Diabetes. Endocrine Reviews, 32(4), 515-531. https://doi. org/10.1210/er.2010-0029

27. Wilding, J. P. H., Norwood, P., T'joen, C., Bastien, A., List, J. F., \& Fiedorek, F. T. (2009). A Study of Dapagliflozin in Patients With Type 2 Diabetes Receiving High Doses of Insulin Plus Insulin Sensitizers: Applicability of a novel insulin-independent treatment. Diabetes Care, 32(9), 1656-1662. https:// doi.org/10.2337/dc09-0517

28. Boussageon, R., Bejan-Angoulvant, T., SaadatianElahi, M., Lafont, S., Bergeonneau, C., Kassai, B., ... Cornu, C. (2011). Effect of intensive glucose lowering treatment on all cause mortality, cardiovascular death, and microvascular events in type 2 diabetes: metaanalysis of randomised controlled trials. BMJ, 343 (jul26 1), d4169-d4169. https://doi.org/10.1136/bmj.d4169

29. The ORIGIN Trial Investigators, O. (2012). Basal Insulin and Cardiovascular and Other Outcomes in Dysglycemia. New England Journal of Medicine, 367(4), 319-328. https://doi.org/10.1056/ NEJMoa1203858

30. Patil, H. R., Al Badarin, F. J., Al Shami, H. A., Bhatti, S. K., Lavie, C. J., Bell, D. S. H., \& O'Keefe, J. H. (2012). Meta-Analysis of Effect of Dipeptidyl Peptidase-4 Inhibitors on Cardiovascular Risk in Type 2 Diabetes Mellitus. The American Journal of Cardiology, 110(6), 826-833. https://doi.org/10.1016/j.amjcard.2012.04.061

31. Boland, C. L., DeGeeter, M., Nuzum, D. S., \& Tzefos, M. (2013). Evaluating Second-Line Treatment Options for Type 2 Diabetes: Focus on Secondary Effects of GLP-1 Agonists and DPP-4 Inhibitors. Annals of Pharmacotherapy, 47(4), 490-505. https://doi. org/10.1345/aph.1R444

32. Jackness, C., Karmally, W., Febres, G., Conwell, I. M., Ahmed, L., Bessler, M., ... Korner, J. (2013). Very Low-Calorie Diet Mimics the Early Beneficial Effect of Roux-en-Y Gastric Bypass on Insulin Sensitivity and $\beta$-Cell Function in Type 2 Diabetic Patients. Diabetes, 62(9), 3027-3032. https://doi.org/10.2337/db12-1762

33. Steven, S., Hollingsworth, K. G., Al-Mrabeh, A., Avery, L., Aribisala, B., Caslake, M., \& Taylor, R. (2016). Very Low-Calorie Diet and 6 Months of Weight Stability in Type 2 Diabetes: Pathophysiological Changes in Responders and Nonresponders. Diabetes Care, 39(5), 808-815. https://doi. org/10.2337/dc15-1942

34. Taylor, R. (2016). Calorie restriction and reversal of type 2 diabetes. Expert Review of Endocrinology \& Metabolism, 11(6), 521-528. https://doi.org/10.1080/1744 6651.2016.1239525 
35. Mitrakou, A., Kelley, D., Veneman, T., Jenssen, T., Pangburn, T., Reilly, J., \& Gerich, J. (1990). Contribution of Abnormal Muscle and Liver Glucose Metabolism to Postprandial Hyperglycemia in NIDDM. Diabetes, 39(11), 1381-1390. https://doi.org/10.2337/ diab.39.11.1381

36. Gerich, J. E., Lorenzi, M., Bier, D. M., Schneider, V., Tsalikian, E., Karam, J. H., \& Forsham, P. H. (1975). Prevention of Human Diabetic Ketoacidosis by Somatostatin. New England Journal of Medicine, 292(19), 985-989. https://doi.org/10.1056/NEJM197505082921901

37. Hayami, T., Kato, Y., Kamiya, H., Kondo, M., Naito, E., Sugiura, Y., ... Nakamura, J. (2015). Case of ketoacidosis by a sodium-glucose cotransporter 2 inhibitor in a diabetic patient with a low-carbohydrate diet. Journal of Diabetes Investigation, 6(5), 587-590. https://doi.org/10.1111/ jdi.12330

38. Coll, A. P., \& Thomas, S. (2004). Diabetic ketoacidosis presenting in a patient with Addison's disease. Diabetic Medicine, 21(10), 1155-1156. https://doi.org/10.1111/j.14645491.2004.01303.x

39. Sucunza, N., \& Corcoy, R. (2005). Inadequatetreatment causing fasting ketoacidosis in a patient with Addisonian crisis. Journal of Endocrinological Investigation, 28(10), 768-769. https://doi.org/10.1007/BF03347562

40. Hsieh, S., \& White, P. C. (2011). Presentation of Primary Adrenal Insufficiency in Childhood. The Journal of Clinical Endocrinology \& Metabolism, 96(6), E925E928. https://doi.org/10.1210/jc.2011-0015

41. Toth, H. L., \& Greenbaum, L. A. (2003). Severe acidosis caused by starvation and stress. American Journal of Kidney Diseases, 42(5), e22.1-e22.4. https://doi.org/10.1016/j.ajkd.2003.07.012

42. Frise, C. J., Mackillop, L., Joash, K., \& Williamson, C. (2013). Starvation ketoacidosis in pregnancy. European Journal of Obstetrics \& Gynecology and Reproductive Biology, 167(1), 1-7. https://doi. org/10.1016/j.ejogrb.2012.10.005

43. Causso, C., Arrieta, F., Hernández, J., BotellaCarretero, J. I., Muro, M., Puerta, C., ... Vázquez, C. (2010). Severe ketoacidosis secondary to starvation in a frutarian patient. Nutricion Hospitalaria, 25(6), 1049-1052. Retrieved from http://www.ncbi.nlm. nih.gov/pubmed/21519781

44. Valkenborgh, T., \& Bral, P. (2013). Starvationinduced ketoacidosis in bariatric surgery: a case report. Acta Anaesthesiologica Belgica, 64(3), 115117. Retrieved from http://www.ncbi.nlm.nih.gov/ pubmed/24279201

45. Andalib, A., Elbahrawy, A., Alshlwi, S., Alkhamis, A., Hu, W., Demyttenaere, S., ... Court, O. (2016). Diabetic Ketoacidosis Following
Bariatric Surgery in Patients With Type 2 Diabetes: Table 1. Diabetes Care, 39(8), e121-e122. https:// doi.org/10.2337/dc16-0280

46. Van Den Berghe, G., Wouters, P., Weekers, F., Verwaest, C., Bruyninckx, F., Schetz, M., Vlasselaers, D., Ferdinande, P., Lauwers, P. and Bouillon, R., 2001. Intensive insulin therapy in critically ill patients. New England journal of medicine, 345(19), pp.1359-1367.

47. Unger, R. H., Eisentraut, A. M., \& Madison, L. L. (1963). The Effects of Total Starvation Upon The Levels Of Circulating Glucagon And Insulin In Man*. Journal of Clinical Investigation, 42(7), 1031-1039. https://doi.org/10.1172/JCl104788

48. Famulla, S., Pieber, T. R., Eilbracht, J., Neubacher, D., Soleymanlou, N., Woerle, H. J., ... Kaspers, S. (2017). Glucose Exposure and Variability with Empagliflozin as Adjunct to Insulin in Patients with Type 1 Diabetes: Continuous Glucose Monitoring Data from a 4-Week, Randomized, Placebo-Controlled Trial (EASE-1). Diabetes Technology \& Therapeutics, 19(1), 496o. https://doi.org/10.1089/dia.2016.0261

49. Pieber, T. R., Famulla, S., Eilbracht, J. Cescutti, J., Soleymanlou, N., Johansen, O. E., ... Kaspers, S. (2015). Empagliflozin as adjunct to insulin in patients with type 1 diabetes: a 4-week, randomized, placebo-controlled trial (EASE-1). Diabetes, Obesity and Metabolism, 17(10), 928935. https://doi.org/10.1111/dom.12494

50. Mathieu, C., Dandona, P., Gillard, P., Senior, P., Hasslacher, C., Araki, E., ... Langkilde, A. M. (2018). Efficacy and Safety of Dapagliflozin in Patients With Inadequately Controlled Type 1 Diabetes (the DEPICT-2 Study): 24-Week Results From a Randomized Controlled Trial. Diabetes Care, 41(9), 1938-1946. https://doi.org/10.2337/ dc18-0623

51. Pilz, S., Scharnagl, H., Tiran, B., Seelhorst, U., Wellnitz, B., Boehm, B. O., ... März, W. (2006). Free Fatty Acids Are Independently Associated with All-Cause and Cardiovascular Mortality in Subjects with Coronary Artery Disease. The Journal of Clinical Endocrinology \& Metabolism, 91(7), 2542-2547. https://doi.org/10.1210/jc.20060195

52. Food US, Administration D, others. FDA Briefing Document: Endocrine and Metabolic Drug Advisory Committee Meeting, June 28, 2016.

53. Safety Warning: Risk of diabetic Ketoacidosis (DKA, ketoacidosis diabetic) while using SGLT2 inhibitors. 14/01/2018. Ministry of Health. Israel. https://www.health.gov.il/NewsAndEvents/ Recall_drugs/DocLib1/400314419.pdf 


\title{
Информация 06 авторах
}

Шмуэль Левит* - д-р мед. наук, руководитель Института эндокринологии, диабета и метаболизма, Медицинский центр Ассута, ул. Хабарзель, 10, Тель-Авив 6971028, Израиль; Профессор Казанского национального исследовательского технологического университета, Российская Федерация, ул. Карла Маркса, 68, Казань, Республика Татарстан, 420015, Россия; e-mail: shmuelle@assuta.co.il, +972 (0) 508805375, ORCID: 0000-0003-0406-8021

Шмуэль Меир Гивон - д-р мед. наук, магистр здравоохранения, руководитель исследовательского отдела, отдела управления Шарон-Шомрон, больничная касса "Клалит», ул. Хамлаха, 39, Южная Нетания 4250571, Израиль; e-mail: giveon@clalit.org.il, + 972- (0) 50-6264969, ORCID: 0000-0002-3638-0055

\begin{abstract}
Ильдар Наильевич Мусин - канд. техн. наук, доцент, заведующий кафедрой медицинской информатики, Казанский национальный исследовательский технологический университет, Российская Федерация, ул. Карла Маркса, 68, Казань, Республика Татарстан, 420015, Россия; e-mail: ildarmusin@mail.ru Скопус идентификатор: 57193350975. Веб-сайт научного сотрудника ID: V-3175-2017 ORCID: 0000-0003-4516-4183;
\end{abstract}

Рой Барни - д-р мед. наук, ведущий исследователь Научноисследовательского института здоровья сети медицинских центров "Ассута», ул. Хабарзель 20. Тель-Авив 6971028, Израиль; e-mail: royib@assuta.co.il, +972 (0) 508804581, ORCID: 0000 -0002-6119-9725

Ифат Корек-Абади - д-р мед. Наук, директор по научно-исследовательским вопросам отдела науки и исследований Медицинского центра "Ассута» сети медицинских центров "Ассута», ул. Хабарзель 20. ТельАвив 6971028, Израиль; e-mail: ifata@assuta.co.il, +972 (0) 37644043, ORCID: 0000-0002-2771-8819.

Вячеслав Левит - врач высшей категории, заведующий отделением медицинской профилактики, Городская клиническая больница №8, Челябинск, Россия; e-mail: slava_levit@mail.ru, +7-951-118-51-95, ORCID 0000-0003-1306-1374

Дариан Райдер - д-р мед. наук, Лаборатория виртуальной реальности и нейро-познания, Технион - Израильский технологический институт, Хайфа, 3200003, Израиль; e-mail: Darian@Neurologit.com, +972 (0) 585-963-963, ORCID: 0000-0001-9691-7136

Хен Ханна Райдер - д-р мед. наук, ведущий исследователь, руководитель лаборатории исследования мозга, отделение неврологии, медицинский центр Зив, Дерех а-Рамбам, Цфат, 13100, Израиль; Медицинский факультет, Университет Бар-Илан, ул. Генриетты Сольд 8, Цфат, Израиль; e-mail:chen.r@ziv.health.gov.il, +972 (0) 77-682-83-16, ORCID: 0000-0002-9028-1154 


\section{Author information}

Shmuel Levit* - M.D. Ph.D. Head of Institute of Endocrinology, Diabetes \& Metabolism, Assuta Medical Center, Tel Aviv, Israel; Professor of Kazan National Research Technological University. Russian Federation, Str. Karl Marx, 68, Kazan, Republic Tatarstan 420015, Russia; e-mail: shmuelle@assuta. co.il, +972(0)508805375, ORCID: 0000-0003-0406-8021

Shmuel Meir Giveon - MD, MPH, Head of Research Unit, Sharon-Shomron district management, Clalit Health Services, 39 Hamelacha str. Netanya South 4250571; e-mail: Israel; giveon@clalit.org.il, +972-(0)50-6264969, ORCID: 0000-0002-3638-0055

Ildar Nailevich Musin - PhD of Engineering Science, Head of the Department of medical Informatics, National Research Technological University, Russian Federation, Karl Marx str., 68, Kazan, Republic of Tatarstan, 420015, Russia; e-mail: ildarmusin@mail.ru, Scopus identifier: 57193350975 Web of Science Researcher ID: V-3175-2017 ORCID: 0000-0003-4516-4183

Royi Barnea - PhD, Chief investigator, Assuta Health Services Research Institute,Assuta Medical Centers Network, 20 Habarzel Street, Tel-Aviv 6971028, Israel; e-mail: royib@assuta.co.il, +972(0)508804581, ORCID: 0000-0002-6119-9725

Ifat Korek-Abadi - PhD, Academic and research director, Department of Academy and Research, Assuta Medical Center, Assuta Medical Centers Network, 20 Habarzel str. Tel-Aviv 6971028, Israel; e-mail: ifata@assuta.co.il, +972(0)37644043, ORCID: 0000-0002-2771-8819

Vyacheslav Levit - MD, Head of Disease Prevention Department, City Clinical Hospital №8, Chelyabinsk, Russia; e-mail: slava_levit@mail.ru, +7-951-1185195, ORCID 0000-0003-1306-1374

Darian Ryder - PhD, Virtual-Reality \& Neuro Cognition Lab, Technion - Israel Institute of Technology, Haifa, 3200003; e-mail: Darian@Neurologit.com, +972(0)585-963-963, ORCID: 0000-0001-9691-7136

Chen Hanna Ryder - PhD, Principal Investigator, Head of the Brain Research Laboratory, Department of Neurology, Ziv Medical Center, Derech HaRambam, Safed, 13100, Israel; Faculty of medicine, Bar-llan University, Henrietta Szold St 8, Safed, Israel; e-mail: chen.r@ziv.health.gov.il, +972(0)77-6828316, ORCID:0000-0002-9028-1154 